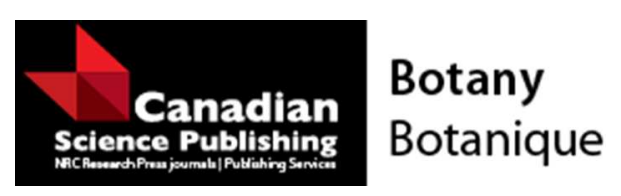

\title{
A review of the plants of the Princeton chert (Eocene, British Columbia, Canada)
}

\begin{tabular}{|r|l|}
\hline Journal: & Botany \\
\hline Manuscript ID & cjb-2016-0079.R1 \\
\hline Manuscript Type: & Review \\
\hline Date Submitted by the Author: & 07-Jun-2016 \\
\hline Complete List of Authors: & $\begin{array}{l}\text { Pigg, Kathleen; Arizona State University, School of Life Sciences } \\
\text { DeVore, Melanie; Georgia College and State University, Department of } \\
\text { Biological \& Environmental Sciences }\end{array}$ \\
\hline Keyword: & $\begin{array}{l}\text { Allenby Formation, Aquatic plants, Fossil monocots, Okanagan Highlands, } \\
\text { Permineralized floras }\end{array}$ \\
\hline \multicolumn{2}{|c}{} \\
\hline
\end{tabular}

\section{SCHOLARONE ${ }^{\text {IM }}$}

Manuscripts 
A review of the plants of the Princeton chert (Eocene, British Columbia, Canada)

Kathleen B. Pigg, School of Life Sciences, Arizona State University, PO Box 874501, Tempe, AZ 85287-4501, USA

Melanie L. DeVore, Department of Biological \& Environmental Sciences, Georgia College \& State University, 135 Herty Hall, Milledgeville, GA 31061 USA

Corresponding author: Kathleen B. Pigg (email: kpigg@asu.edu) 


\title{
A review of the plants of the Princeton chert (Eocene, British Columbia, Canada)
}

\author{
Kathleen B. Pigg and Melanie L. DeVore
}

\begin{abstract}
The Princeton chert is one of the most completely studied permineralized floras of the Paleogene. Remains of over 30 plant taxa have been described in detail, along with a diverse assemblage of fungi that document a variety of ecological interactions with plants. As a flora of the Okanagan Highlands, the Princeton chert plants are an assemblage of higher elevation taxa of the latest early to early middle Eocene, with some components similar to those in the related compression floras. However, like the well known floras of Clarno, Appian Way, the London Clay, and Messel, the Princeton chert provides an additional dimension of internal structure. In the present study, we outline the history of Princeton chert plant research, starting with Boneham and others, and extending into studies by Stockey and her students and colleagues. These studies were undertaken primarily at the University of Alberta, Edmonton. We then reexamine the individual elements of the Princeton chert flora, using the framework of the currently recognized APG III phylogeny and in light of recent fossil discoveries. We hope that this update will bring to mind new aspects of the significance of the Princeton chert flora to Paleogene paleobiology, biogeography and plant evolution.
\end{abstract}

Keywords: Allenby Formation, Aquatic plants, Fossil monocots, Okanagan Highlands, Permineralized floras 


\section{Introduction}

The Princeton chert is an assemblage of latest early to earliest middle Eocene permineralized plants from near Princeton, British Columbia, Canada, and is part of the central Okanagan Highlands area of British Columbia, and Washington, USA (Basinger and Rothwell 1977; Stockey and Wehr 1996; Stockey 2002). The Princeton chert occurs within the Allenby Formation, in a region well known for mining of gold, platinum, copper, and coal prior to European settlement and especially since the 1850s (Greenwood et al. 2016; Town of Princeton, 2016). The earliest study of the chert was a pollen analysis by Boneham (1968) in work included in his Ph.D. dissertation on Tertiary (Paleogene) coal basins of south central British Columbia, Canada, directed by Chester A. Arnold at University of Michigan. In that study Boneham found fungal, bryophyte and algal spores, as well as angiosperm pollen assigned to Pistillipollenites Rouse (Boneham 1968; Robison and Person 1973).

Studies of plant megafossils from the Princeton chert were first published in 1973 by Charles N. Miller, Jr., who described anatomically preserved seed cones and stems of Pinus L. as P. arnoldii Miller and a five-needled fascicle, $P$. similkameenensis Miller (Miller 1973). That same year, from material collected by Arnold, Eorhiza arnoldii Robison \& Person was established for rhizomes, axillary branches, and adventitious roots of one of the most common plants in the chert (Robison and Person 1973). The next work on the Princeton chert was that of James F. Basinger who completed his M.S. thesis (Basinger 1976a) and Ph.D. dissertation (Basinger 1979) at the University of Alberta, Edmonton. His publications included the descriptions of Paleorosa similkameenensis Basinger (Rosaceae, Basinger 1976b) and the vegetative body (Basinger 1981) and seed 
cones (Basinger 1984) of Metasequoia milleri Basinger (Cupressaceae). He also coauthored an overview of the flora and the description of Metasequoia Miki pollen cones with Gar W. Rothwell (Basinger and Rothwell 1977; Rothwell and Basinger 1979).

With her appointment at the University of Alberta in the early 1980s, Ruth A. Stockey began a sustained study of the Princeton chert along with her colleagues, students and postdoctoral associates that continued for the next several decades. This body of work has contributed substantially to our understanding of the taxonomy, anatomy, morphology, and paleoecology of the Princeton chert flora. Stockey's first contributions to the Princeton chert were additional work on Pinus arnoldii and the description of a second type of conifer seed cone, $P$. princetonensis Stockey, the threeneedled fascicles of $P$. andersonii Stockey and, at the stratigraphically equivalent John Allison schoolyard site, the two-needled fascicles of P. allisonii Stockey (Stockey 1984). She also described Princetonia allenbyensis Stockey, a small flower of uncertain affinities (Stockey 1987).

From the late 1980s into the early 1990s, Stockey's Ph.D. students Sergio R. S. Cevallos-Ferriz and Diane M. Erwin began publishing on plants from the Princeton chert. Cevallos-Ferriz produced both his M.S. thesis (Cevallos-Ferriz 1987) and Ph.D. dissertation (Cevallos-Ferriz 1990) at the University of Alberta and formally published a series of fruits, seeds, and permineralized woods with Stockey, including the following: Decodon similkameenensis Cevallos-Ferriz \& Stockey fruits and seeds (Lythraceae, Cevallos-Ferriz and Stockey 1988a); Keratosperma allenbyensis Cevallos-Ferriz \& Stockey fruits and seeds (Araceae, Cevallos-Ferriz and Stockey 1988b); Allenbya collinsonae Cevallos-Ferriz \& Stockey seeds and probable fruits (Nymphaeaceae, 
Cevallos-Ferriz and Stockey 1989); three types of unnamed Prunus L. endocarps (Rosaceae, Cevallos-Ferriz and Stockey 1991) and Prunus allenbyensis Cevallos-Ferriz \& Stockey twig wood (Cevallos-Ferriz and Stockey 1990a); wood of Liriodendroxylon princetonensis Cevallos-Ferriz \& Stockey (Magnoliaceae, Cevallos-Ferriz and Stockey 1990b) and three types of vitaceous seeds including Ampelocissus similkameenensis Cevallos-Ferriz \& Stockey and two unnamed forms (Vitaceae, Cevallos-Ferriz and Stockey 1990c). Cevallos-Ferriz et al. (1993) restudied Paleorosa similkameenensis and emended the diagnosis to include additional morphological details. He also served as lead author in a paper discussing the aquatic nature of Princeton chert plants (Cevallos-Ferriz et al. 1991).

Diane Erwin's work on the Princeton chert culminated in her Ph.D. dissertation research (Erwin 1991) and focused primarily on the vegetative remains of selected monocot taxa (Erwin and Stockey 1991a). These included Heleophyton helobieoides Erwin \& Stockey (Alismataceae, Erwin and Stockey 1989); Soleredera rhizomorpha Erwin \& Stockey (Liliales, Erwin and Stockey 1991b); Ethela sargentiana Erwin \& Stockey (Cyperaceae/Juncaceae, Erwin and Stockey 1992), and a coryphoid palm, Uhlia allenbyensis Erwin \& Stockey (Arecaceae, Erwin and Stockey 1994). In addition, Wehrwolfea striata Erwin \& Stockey (Sapindaceae, Erwin and Stockey 1990) was described for a small, staminate flower with in situ pollen.

Postdoctoral associate Kathleen B. Pigg worked with Stockey in 1989, with the collaboration resulting in the description of a guava-like fruit Paleomyrtinaea Pigg, Stockey \& Maxwell (Myrtaceae, Pigg et al. 1993), further analysis of the distinctive flowers and young fruits of Princetonia allenbyensis (Stockey and Pigg 1991), and a 
description of the leaves, branches, and growth architecture of the rhizomatous, semiaquatic plant Eorhiza arnoldii (Robison and Person 1973; Stockey and Pigg 1994). Benoit A. LePage worked as a postdoctoral associate in the Stockey lab in the early-mid 1990s and collaboratively studied Diplopanax eydei Stockey, LePage \& Pigg (Cornaceae, Stockey et al. 1998). Mycologist Randy Currah collaborated with Stockey, LePage, and others in an analysis of the fossil fungi in the Princeton chert (Currah and Stockey 1991; LePage et al. 1994, 1997; Currah et al. 1998; Stockey et al. 2001). [It should be noted that specimens described as smut fungi from the anthers of small flowers (Currah and Stockey 1991) turned out to be the pollen grains of Saururus tuckerae (Smith and Stockey 2007a, b)].

Two additional students, Stefan A. Little and Selena Y. Smith obtained their Ph. D. degrees from the Stockey lab in the mid 2000's with their primary research based on plants of the Princeton chert (Little 2006; Smith 2007). Little's work was on the vegetative morphology of plants in Lythraceae including the anatomy and development of unusual bark tissues of Decodon allenbyensis (Little and Stockey 2003, 2005) and associated leaves that resemble the extant Old World mangrove plant Duabanga grandiflora (Roxb. ex DC.) Walpers. (Little et al. 2004). Little, Stockey and Penner also studied unnamed inflorescences and flowers assignable to Lauraceae (Little et al. 2009).

Selena Smith's Princeton chert studies included a revision of Keratosperma allenbyense Cevallos-Ferriz \& Stockey emend. Smith \& Stockey (Araceae, Smith and Stockey 2003) and the description of Saururus tuckerae Smith \& Stockey (Saururaceae, Smith and Stockey 2007a, b). Smith also contributed to the understanding of filicalean fern diversity in the Princeton chert with the description of an extinct fern Trawetsia 
princetonensis Smith, Stockey, Nishida \& Rothwell (Blechnaceae, Smith et al. 2006).

Smith has illustrated several Princeton chert plants in more recent discussions of the value of nondestructive computer tomography techniques (Smith et al. 2009). Steven J. Karafit completed a M.S. degree from University of Alberta and worked on the fossil fern Dickwhitea allenbyensis Karafit, Stockey, Rothwell \& Nishida (Athyriaceae, Karafit et al. 2006). A number of additional undergraduate assistants also helped with these projects. Mr. Gordon Chan worked as laboratory assistant to the Stockey lab for many years during the time of this research, and much of the scanning electron microscopy was done with George Braybook, Department of Geology at the University of Alberta. Other contributors to studies of the Princeton chert flora include Harafumi Nishida, who collaborated on the descriptions of the filicalean ferns Makotopteris princetonensis Stockey, Nishida \& Rothwell (Athyriaceae, named for his father, paleobotanist Makoto Nishida; Stockey et al. 1999) and Trawetsia princetonensis (Blechnaceae, Smith et al. 2006). Gar W. Rothwell contributed to early studies of the Princeton chert (Basinger and Rothwell 1977 ; Rothwell and Basinger 1979), as well as more recent reports on ferns and conifers (Stockey et al. 1999; Karafit et al. 2006; Smith et al. 2006; Klymiuk et al. 2011).

Additional authors who collaborated with Stockey are Carlie J. Phipps, and Jeffrey M. Osborn, who studied Pinus pollen cones with in situ pollen (Phipps et al. 1995), and, more recently, Ashley A. Klymiuk who coauthored the whole plant reconstruction of Pinus arnoldii Miller emend. Klymiuk, Stockey \& Rothwell (Klymiuk et al. 2011). Klymiuk also produced studies on fungi associated with Princeton chert plants (Klymiuk et al. 2013a, b; Klymiuk 2014). In addition to megafossil remains from 
the Princeton chert, pollen obtained from the chert matrix has been illustrated and described in several publications (Ferguson et al. 2007; Hesse and Zetter 2005, 2007; Grímsson et al. 2012, 2014; Manchester et al. 2015a). To our knowledge these occurrences have not been summarized.

Several summaries of the Princeton chert flora are available. Cevallos-Ferriz et al. (1991) provided an initial summary that emphasized the aquatic nature of many floral elements. Stockey and Wehr (1996) included a checklist in their chapter on plant fossils of British Columbia, and Pigg and Stockey (1996) provided a detailed, updated list of plants and fungi. Stockey (2002) gave a brief summary of the flora and its significance as a Lagerstätte, or exceptionally preserved flora.

In the current contribution, we review the taxonomic and phylogenetic positions of the plants described in the Princeton chert. We update the list of taxa from the Princeton chert, and document their significance to our current understanding of the fossil record and phylogenetic relationships of the plants. We also wish to describe the chert within a paleoecological context that is consistent with our understanding of the locality on both local and regional scales. Lastly, we speculate on how new insights about the phylogeny of selected Princeton chert plants in future studies that might contribute to the value of these permineralized plants to broader understanding of the Eocene upland landscape, the plants that lived there, and their evolutionary connections to the present day temperate floras of the Northern Hemisphere.

\section{Geologic setting}

The Princeton chert locality occurs on the east bank and extending out into the 
Similkameen River in south central British Columbia, approximately $8.4 \mathrm{~km}$ south of the town of Princeton (Fig. 1A, Boneham 1968; Basinger and Rothwell 1977; Mustoe 2011). There are 49 main layers of interbedded cherts and coals, some of them splittling, and occasionally anastomosing, resulting in approximately 70 thinner sublayers (Smith et al. 2006). The process of cyclic deposition of coals and cherts occurred within a faultbounded basin, suggesting that the material was locally sourced. Because the thrust faults surrounding the basin were so deep, superheated waters along the fault lines rose and formed thermal vents (hot springs) as ground water was recharged (McMechan 1983; Read 2000). These mineral-rich waters infiltrated plant tissues at a cellular level eventually becoming supersaturated, crystalizing, and trapping the plant tissues. Diagenesis of cherts may be linked with productivity mechanisms of organisms with siliceous tests, however, explaining how cyclic Si enrichment would be associated with a meandering system is something not clearly addressed in Mustoe's (2011) model.

Stratigraphically, the Princeton chert occurs within the Ashnola shale (Ashnola chert of Wilson 1980) in the Allenby Formation (Read 2000). Previously, the chert was thought to be of middle Eocene age based on regional correlations of mammal fossils (Russel 1935) and pollen (Boneham 1968), and radiometric dates based on K-Ar dating of volcanic sediments at the site of the former mining town of Allenby near the chert locality (Hills and Baadsgaard 1967; Little et al. 2009). A more recent, unpublished radiometric date of 48.7 Ma (lacking an age certainty value) was produced for ash layer \#22 within the chert itself (Smith et al. 2006; DeVore and Pigg 2009). This value is consistent with recent regional radiometric dating of Allenby Formation volcanics (Ickert et al. 2009). The early-middle Eocene boundary is now set at 47.8 Ma (Cohen and 
Gibbard 2015), and the Ashnola shale is relatively high in the Allenby Formation (Boneham 1968; McMechan 1983; Read 2000). Consequently, the Princeton chert appears to be the youngest of the Okanagan Highlands floras, either latest early Eocene or earliest middle Eocene.

The chert is prepared for study with a modification of the cellulose acetate peel technique of Joy et al. (1956) that uses hydrofluoric acid to dissolve the silicates (Basinger and Rothwell 1977). Additional studies frequently include scanning electron microscopy (SEM) of plant tissues, and SEM and transmission electron microscopy (TEM) of pollen wall layers. Three-dimensional software has been used to reconstruct plant organs from serial sections. Below we use the APG III (Angiosperm Phylogeny Group) outline for the organization of the flora discussed below (Stevens 2001 onwards, accessed online 8 January 2016) and InsideWood (2004-onwards. accessed online 6 March 2016; Wheeler 2011) for sections on fossil Magnoliaceae and Rosaceae wood.

\section{Results}

To date, 23 genera and 32 species of vascular plants, representing 21 families plus incertae sedis, have been described from the Princeton chert formally (Appendix A1; Fig. 1B-D). Lauraceous fruits were described but not named (Little et al. 2009), and a contributed paper on a Ribes fruit was presented, but the specimen was not described further (Cevallos-Ferriz 1995). Plant organs found in the chert include leaves, roots, stems, cones, buds, flowers, fruits and seeds, that are sometimes found in organic connection to one another. Some flowers have in situ pollen (Princetonia, Stockey and Pigg 1991; Wehrwolfea, Erwin and Stockey 1990; Saururus, Smith and Stockey 2007a, 
b), and, some ferns, in situ spores (Makotopteris, Stockey et al. 1999).

Isolated palynomorphs also have been described from the chert matrix (Boneham 1968; Hesse and Zetter 2005, 2007; Ferguson et al. 2007; Grímsson et al. 2012, 2014; Manchester et al. 2015a). Although Boneham (1968) found only Pistillipollenites pollen, along with fungal, bryophyte and algal spores, more recent studies using single grain analysis whereby an individual pollen grain is studied with both light and scanning electron microscopy have yielded additional pollen taxa. Pararisteapolles stockeyi Zetter \& Hesse, is a zona-aperturate grain assigned to Asparagales and the iris family Iridaceae on the basis of its similarities to extant Aristea Sol. pollen (Hesse and Zetter 2005). In particular, this pollen type most closely resembles members of Aristea subgenus Pseudoaristea and subgenus Aristea, in particular Aristea biflora Weim. or A. lugens (L. f.) Steud. (Goldblatt and Le Thomas 1997; Goldblatt et al. 2004). A second occurrence of pollen from the Princeton chert is that of the so-called "Anemopsipolles" type found in the family Saururaceae (Ferguson et al. 2007; Smith and Stockey 2007a,b). Decodon (Lythraceae) pollen is known from the chert (Grímsson et al. 2012), as is Aponogeton Planch. (Alismatales, Aponogetonaceae, Grímsson et al. 2014). Layer 43 of the Princeton chert yielded samples of asterid pollen including members of Oleaceae (Lamiales), Aralia L.-like pollen (Apiales, Araliaceae), Viburnum L. (Dipsacales, Caprifoliaceae) and tentatively described asteraceous forms (Manchester et al. 2015a).

Fungi are also well known in the chert, both for their taxonomic diversity and varied ecological roles (LePage et al. 1994, 1997; Currah and Stockey 1991; Currah et al. 1998; Stockey et al. 2001; Klymiuk et al. 2013a, b). The occurrence, taxonomic diversity, and consideration of the potential ecological roles of Princeton chert fungi are 
summarized in Klymiuk et al. (2013a, b) and Klymiuk (2014, 2016). Fossil fish have been recovered from a shale above the chert beds, along with a soft-shelled turtle, including an articulated amiid fish, Amia L., reconstructed as a deep-bodied piscivore; and disarticulated remains of small suckers belonging to the genus, Amyzon Cope (Catostomidae) and trout perches, (Libotanius sp., Percopsidae), (Wilson 1982; Cevallos-Ferriz et al. 1991).

\section{FERNS}

\section{Filicales}

Five types of filicalean ferns in four families have been described from the Princeton chert. Two, Osmunda L. and Dennsteadtiopsis arenchymata Arnold and Daugherty, are well known representatives of Eocene floras of western North America, whereas the other three, Trawetsia princetonensis, Makotopteris princetonensis, and Dickwhitea allenbyensis, are newly described from the Princeton chert (Appendix A1).

Osmundaceae: Osmunda sp. (Pigg and Stockey 1996; Karafit et al. 2006) has been reported informally by Rothwell on the basis of a single frond rachis (Collinson 2001). Given the large number of specimens that have been studied from the Princeton chert, even if additional specimens are found, Osmunda is apparently extremely rare at this site.

The Osmundaceae has an extensive fossil record extending back into the Paleozoic (Miller 1971; Bomfluer et al. 2015). Cretaceous, Paleogene, and Neogene genera of Osmundaceae are summarized by Collinson $(2001,2002)$ and are known typically from vegetative remains such as stems, stipes, and adventitious roots, as is the case here. More rarely, reproductive structures are found (Vavrek et al. 2006). Recent 
molecular studies have shown traditional Osmunda to be paraphyletic, resulting in the recognition of Osmundastrum for the former Osmunda cinnamomea (Metzgar et al. 2008). Other species, and presumably the Princeton chert fossil, remain in the genus Osmunda.

Dennstaedtiaceae: Dennstaedtiopsis aerenchymata, first described from the Clarno Formation of Oregon (Arnold and Daugherty 1964) was documented also in some of the earliest studies of the Princeton chert (Basinger 1976a; Basinger and Rothwell 1977) and discussed as an aquatic plant (Cevallos-Ferriz et al. 1991). Numerous vegetative remains of rhizomes, stipes and higher order frond segments are relatively common in selected layers of the chert (Fig. 1B, Pigg, personal observation, 1996), however, reproductive structures are yet to be found. The Princeton chert dennsteadtiaed fern is similar in all known anatomical features to the Clarno fern described by Arnold and Daugherty (1964). These ferns have a simple solenostele and produce stipes with long internodes between them. They contain abundant aerenchyma and are anatomically similar to their modern relative Dennstaedtia Bernh. In a separate context, specimens of Dennsteadtiopsis from the Princeton chert were recently studied for the presence of permineralized kerogen (Czaja et al. 2009).

The Cenozoic fossil record of the dennsteadiod ferns was summarized by Collinson (2001, 2002). Serbet and Rothwell (2003) further discussed the fossil record of the family in their description of the Late Cretaceous fern Microlediopsis from central Alberta.

Blechnaceae: Trawetsia princetonensis (Blechnaceae, Smith et al. 2006), an extinct genus in the family Blechnaceae, is based on vegetative remains that include 
rhizomes, stipes, higher order frond members, and adventitious roots that all share features with several different members of the family. Rhizomes are dictyostelic with amphiphloic cauline bundles containing sclerenchyma on both inner and outer sides. The ground tissues have small nests of sclerotic cells within a parenchymatous/ aerenchymatous matrix. Stipes have two larger adaxial hippocampiform vascular bundles accompanied by several small bundles. The specimens are covered by sparse scales throughout (Smith et al. 2006).

The Blechnaceae are today a family of 10 genera. Of its two largest genera, Blechnum L. is found mostly in the Southern Hemisphere, and Woodwardia J. Smith has a Northern Hemisphere distribution. The fossil record of Woodwardia extends from the Paleocene on, and is especially rich in the Miocene of Europe, North America, and Asia (McIver and Basinger 1993; Pigg and Rothwell 2001; Collinson 2001, 2002; Cranfill and Kato 2003).

Athyriaceae: Two dryopterid ferns are known from the Princeton chert. Makotopteris princetonensis (Stockey et al. 1999) was described from both vegetative and reproductive remains and Dickwhitea allenbyensis (Karafit et al. 2006) from rhizomes and frond stipes. Both ferns produce paired hippocampiform leaf traces, as is characteristic of onocleoid fern architecture. Makotopteris is assignable to the family on the basis of many features of rhizome and frond architecture, sori and in situ spores. A lack of some details of fossil frond morphology, and of anatomical features of related extant ferns prevents a close placement in relation to modern genera (Stockey et al. 1999). Dickwhitea rhizomes are unusual in having essentially eustelic architecture, previously unrecorded for filicalean ferns (Karafit et al. 2006). These two genera have a 
vascular architecture that is similar to that of Wessiea yakimaensis Pigg \& Rothwell, a middle Miocene fern from Yakima Canyon, Washington (Pigg and Rothwell 2001).

\section{GYMNOSPERMS}

\section{Pinales}

It is interesting that the pines and Metasequoia, discussed below (Fig. 1C) are the only conifers known from the Princeton chert, given the abundance of conifers in the compression floras of the Okanagan Highlands (Wehr and Schorn 1996; Greenwood et al. 2016).

Pinaceae: Pinus is the only genus of Pinaceae known from the Princeton chert, and it is known from several types of remains including woody stems, leaf fascicles in several numbers, ovulate cones with seeds containing megagametophytes and embryos, and pollen cones with in situ pollen.

Pinus arnoldii has been reconstructed as a "whole plant" (Klymiuk et al. 2011) based on interconnected organs, anatomical similarities co-occurrence of previously described organs and newly acquired specimens. Ovulate cones and stems were described by Miller (1973) with additional details of seed morphology, megagametophytes and embryos added by Stockey (1984). Later, pollen cones with in situ pollen were recognized (Phipps et al. 1995), as were roots with ectomycorrhizae (LePage et al. 1997). Leaf fascicles with five leaves described by Miller (1973) as Pinus similkameenensis were found in organic attachment with Pinus arnoldii stems (Klymuik et al. 2011).

Interestingly, when individual organs are compared with modern Pinus taxa they come out most closely allied to a combination of different groups. Ovulate cones are 
closest to Pinus subgenus Pinus, section Pinus; leaves to Pinus subgenus Strobus section Quinquefoliae; and wood to Pinus subgenus Strobus section Parrya. Phylogenetic analysis documented a placement of the whole-plant Pinus arnoldii as positioned either near the base of Pinus subgenus Pinus or outside all of the extant subgenera (Klymiuk et al. 2011). Klymiuk et al. (2011) used the phylogeny of Gernandt et al. $(2005,2008)$ as the framework for their phylogenetic analysis. An additional recent analysis of the genus is by $\mathrm{Xu}$ et al. (2015).

Other species of Pinus were described by Stockey (1984), including a second ovulate cone, Pinus princetonensis that differs from that of Pinus arnoldii anatomically in several features of the cone axis (Phipps et al. 1995; Klymiuk et al. 2011). Pinus princetonensis compares favorably with Pinus section Pinus subsection sylvestris. Threeneedled fascicles from the chert were named P. andersonii and ascribed to Pinus subgenus Pinus subsection Ponderosae, and leaves of P. allisonii, from the John Allison schoolyard site resemble those of Pinus subgenus Pinus, subsection Sylvestrae. Ectomycorrhizal fungi are known in the corolloid roots of $P$. arnoldii (LePage et al. 1997; Klymiuk et al. 2011).

Erwin and Schorn (2006) suggested similarities of compressed Pinus baileyi Axelrod emend. Erwin \& Schorn from the Paleogene of Idaho and Nevada with $P$. arnoldii and $P$. princetonensis permineralized ovulate cones. The main common characters they note are the excentric placement of the mucro and absence of an umbo. Size and general organization of the $P$. baileyi cones are similar to $P$. arnoldii and $P$. princetonensis, although because of the lack of anatomical preservation, P. baileyi cannot be referred to either species. Erwin and Schorn (2006) note the presence of additional 
hard pines at Republic (Schorn and Wehr 1996), and on into the Eocene in Nevada, and Eocene and Oligocene in Idaho and suggest these occurrences represent an early diversification of Pinus section Pinus subsection Pinus in western North America.

Cupressaceae: Metasequoia milleri is known from stems, leaves, and seed and pollen cones. Organic interconnections and anatomical similarities among these separate plant organs have been demonstrated, providing the evidence necessary for a whole plant reconstruction for this taxon (Rothwell and Basinger 1979; Basinger 1981, 1984). Although taxodiaceous conifers are among the most common taxa found in Late Cretaceous floras and throughout the Paleogene of western North America, they are known most typically as compression/impression plant remains. Metasequoia milleri is one of the most completely known permineralized cupressaceous conifers in the fossil record. Vescicular-Arbuscular (VAM) fungi of the Paris type, quite similar to those in $M$. glyptostroboides are known in the roots of Metasequoia milleri (Stockey et al. 2001).

\section{ANGIOSPERMS}

\section{ANITA grade:}

\section{Nymphaeales}

Nymphaeaceae: Allenbya collinsae is based on numerous water lily seeds and associated probable fruit remains and is a common element of the dominantly aquatic plant layers of the Princeton chert. In comparison with extant seeds of Nymphaeaceae, Allenbya appears to be most closely related to Victoria Lindley, the giant water lily, on the basis of seed coat layers, epidermal cells with sinuous anticlinal walls, and relatively large seeds with an operculum (Cevallos-Ferriz and Stockey 1989). Extant Victoria typically comes out as the most derived member of the lineage (Les et al. 1991, 1999; 
Moseley et al. 1993). It is interesting that seeds and fruits with Victoria-like features, as seen in Allenbya, are already present in the Eocene. A relationship to Victoria has been suggested also for a Cretaceous mesofossil, Microvictoria Gandolfo, Nixon \& Crepet, potentially extending the age of this lineage considerably (Gandolfo et al. 2004). Some authors have considered alternative identifications for this small Cretaceous flower (e.g., Endress 2008).

A robust fossil record based on dispersed seeds, has been known for Nymphaeales throughout the Paleogene and Neogene for some time (Collinson 1980; Cevallos-Ferriz and Stockey 1989; Taylor et al. 2006). Recent discoveries from sites of Cretaceous and younger age have provided new information about fossil nymphaealean plants, their distribution and relationships to modern lineages, as reviewed by DeVore et al. (2015). We now have additional evidence for both vegetative and reproductive organs of an Eocene Nuphar Sibth. \& Sm., N. carlquistii DeVore, Taylor \& Pigg from Republic, Washington, that demonstrates striking similarities in structure and habitat to extant Nuphar (DeVore et al. 2015).

\section{Magnoliids:}

\section{Magnoliales}

Magnoliaceae: Magnoliaceous twig wood found in the Princeton chert was named Liriodendroxylon princetonensis for its similarities with modern wood of the "tulip popular," Liriodendron (Cevallos-Ferriz and Stockey 1990). The species is based on numerous twigs and one large stem that each have a chambered pith and characteristic wood anatomical features of Magnoliaceae. This wood is quite similar to Liriodendroxylon multiporosum Scott \& Wheeler from the Middle Eocene Clarno 
formation of Oregon (Wheeler and Manchester 2004) and L. tulipiferum Prakash, Brezinova \& Bůžek from the Oligocene of Bohemia (Prakash et al. 1971; InsideWood 2004-onwards; Wheeler 2011). There are apparently only small differences in wood anatomy among these three species (Wheeler and Manchester 2004).

For broader discussion of the fossil record and magnoliid phylogeny see Doyle and Endress (2010); Romanov and Dilcher (2013); and Massoni et al. (2015).

\section{Laurales}

Lauraceae: A developmental sequence of flowers and fruits were described by Little et al. (2009) but not formally named. Features include two bracts surrounding trimerous flowers with three whorls of tepals, nine stamens with the characteristic apical valvate dehiscence of lauraceous anthers, in situ psilate pollen, and a single, apically attached, anatropous ovule. The paper beautifully illustrates the transition from flower to fruit with the increase in size, change in configuration of the shallow receptacular cup, and thickening and sclerification of the ovary to become the fruit wall.

Little et al. (2009) discussed the difficulties in identifying lauraceous fruits without the diagnostic characters of floral features and chose not to name the taxon until additional diagnostic information is known (Little et al. 2009). They note that their documentation of developmental changes demonstrates that lauraceous plants were already capable of self-pruning in the Eocene and suggest that the number of lauraceous taxa in the fossil record may be an overestimate, as a result of different developmental stages of the same plant being given different names. More recent study of newly recognized permineralized flowers from the Appian Way site on Vancouver Island documents further diversity in floral features of Lauraceae, particularly in presentation of 
stamens, and suggests that many fossil forms may not be equivalent to any modern taxa (Atkinson et al. 2015).

\section{Piperales}

Saururaceae: Saururus tuckerae was described for a partial inflorescence described as an indeterminate raceme and numerous tiny perianthless flowers with in situ pollen that is monosulcate with a punctate sculpturing (Smith and Stockey 2007a, b). The flowers have five stamens that are adnate to the gynoecium, four basally connate, lobed carpels with one ovule each, and recurved styles. The fossils compare favorably to today's genus Saururus, with minor difference in flower size, pubescence, stamen number, and pollen micromorphology. Modern Saururus, ("lizard's tail"), is an herbaceous, rhizomatous plant common to wetlands of eastern North America and eastern Asia (Wu and Kubitzki 1993).

In situ pollen from Saururus tuckerae, described in detail by Smith and Stockey (2007b) in comparison with extant pollen of the four genera of Saururaceae, is somewhat smaller and has a more regular infratectum than pollen of most of its extant relatives. The informally recognized "Anemopsipolles" pollen type common to the family Saururaceae was described separately from the rock matrix by Ferguson et al. (2007) who used the same grain technique whereby an individual pollen grain is studied by both light and scanning electron microscopy. These authors equated the Princeon chert specimen with pollen of extant Anemopsis. For further discussion of the phylogeny of this group see Massoni et al. (2015).

\section{Monocots}

The evolution of the monocots have been a topic of considerable interest in recent 
years, and several authors have looked to the fossil record for information about the evolution and phylogeny of this group (e.g., Stockey 2006; Smith 2013). Among the most noteworthy contributions of the Princeton chert plants are several reports of anatomically preserved monocots. These include several well documented noncommelids within the orders Alismatales (Araceae and Alismataceae) and less extensive details of fossil Liliales, and commelids within the orders Arecales (Arecaceae) and Poales (Juncaceae/Cyperaceae; Erwin and Stockey 1991a).

\section{Noncommelid moncots}

\section{Alismatales}

Araceae, Subfamily Lasioideae: Keratosperma allenbyense was first described by Cevallos-Ferriz and Stockey (1988) for numerous small campylotropous and reniform seeds with prominent spines. Cevallos-Ferriz and Stockey (1988a) assigned them to Araceae and considered them to be close to the extant genus Cyrtosperma Griff. Later, Smith and Stockey (2003) described additional details of Keratosperma seeds, including the outer surface structure, organization of the raphe and accessory structures such as an epistase, hypostase and podium. They established the identity of Keratospermum within the subfamily Lasioideae on the basis of external seed morphology deduced in part from 3-dimensional reconstruction programs along with detailed anatomical sections of seeds of extant taxa. More recently, Smith et al. (2009) have shown the value of noninvasive technique using CT scan facilities, to understand the complex spiny patterning of Keratosperma seeds.

Based on the completeness of the features known for Keratosperma, Iles et al. (2015) have deemed this taxon suitable for calibrating stem node relationships in 
Araceae. The combination of characters seen in Keratosperma are not present in modern taxa and Keratosperma is thought to be "not appearing closely related to extant genera" (Iles et al. 2015). An additional review of extant Araceae can be found in Cuismano (2011).

[A minor note regarding Araceae pollen occurrence: Hesse and Zetter (2007) describe pollen from the Late Paleocene Joffre Bridge locality which they mistakenly refer to as coming from the "Princeton Chert (Alberta, Canada, Paleocene), courtesy of Dr. Ruth Stockey" (p. 94).]

Alismataceae: Heleophyton helobiacoides was described on the basis of a leaf petiole with monocot-like pattern of vasculature and ground tissue assignable at the family level to Alismataceae (Erwin and Stockey 1989). Because of a lack of detail that would lead to more precise placement Iles et al. (2015) categorized this material as "similar to extant but cannot be placed in crown group".

Aponogetonaceae: Pollen of Aponogeton ("Cape pondweed") was reported from the Late Cretaceous Elk Basin of Wyoming/Montana, the early/middle Eocene Princeton chert, and the Eocene of the small island of Hareø off the coast of West Greenland (Grímsson et al. 2014). Today this monogeneric family is distributed primarily in the Old World tropics and subtropics, where it is represented by small, rhizomatous, aquatic plants. Fossil pollen studied by the same grain technique documents distinctive features in the different localities, in relation to six general types found among extant taxa (Grímsson et al. 2014).

\section{Liliales}

Soleredera rhizomorpha was named for rhizomes with attached roots and 
branches that have features of vegetative morphology that characterize several monocots of the "lilialean families" Liliaceae and Iridaceae (Erwin and Stockey 1991b). Other features of these plants remain yet to be discovered, which limits the information that can be gleaned from these fossils. However, it is interesting in light of these specimens that Pararisteapolles stockeyi, a zona-aperturate pollen assignable to Iridaceae is known now from the Princeton chert (Hesse and Zetter 2005).

\section{Commelid Monocots}

\section{Arecales}

\section{Arecaceae: Coryphoid palm}

Uhlia allenbyensis, named in honor of palm specialist Natalie Uhl, is a small coryphoid palm known from stem, petiole, root, and leaf remains in the Princeton chert (Erwin and Stockey 1991, 1994). Originally noted by Basinger (1976a), additional specimens provided Erwin and Stockey (1994) the opportunity to study these palm remains in greater detail. They interpreted Uhlia's closest affinities to be with the modern genera Rhapidophyllum H. Wendl. \& Drude and Brahea Mart. ex Endl., although the combination of characters found in Uhlia is not congruent with those of any extant genus.

The palm fossil record, particularly of the coryphoid palms, is well known and has been reviewed by several authors (Daghlian 1981; Nambudiri and Tidwell 1998: DeVore and Pigg 2009). A discussion of the biogeography of extant New World coryphoid palms can be found in Bjorholm et al. (2006) and a computer-aided key of stem anatomy of coryphoid palms from Thomas and De Franceschi (2013).

\section{Poales}

\section{Juncaceae/Cyperaceae}


Ethela sargentianea, based on vegetative remains, is thought to have its closest taxonomic affinities to the Cyperaceae/Juncaceae group (Erwin and Stockey 1992). The lack of reproductive structures precludes closer resolution.

\section{Core Eudicots}

\section{Vitales}

Vitaceae: Ampelocissus similkameenensis and two other unnamed vitaceous seed types were described from the chert from a very small number of specimens (CevallosFerriz and Stockey 1990c). The family Vitaceae is generally well represented in the fossil record, both from reproductive and woody stem remains. Vitaceous fossil wood has been reviewed by Wheeler and LaPasha (1994), and seeds by Chen and Manchester (2007) and Manchester et al. (2013). Lui et al. (2016) provided a recent study of extant inflorescence and fruits, along with a phylogenetic perspective on the family.

\section{Rosids I Fabidae}

\section{Rosales}

Rosaceae: The Rosaceae are represented in the Princeton chert flora by endocarps and woody twigs of several types of Prunus (Cevallos-Ferriz and Stockey 1990a, 1991), and by the flower Paleorosa similkameenensis (Basinger 1976b; Cevallos-Ferriz et al. 1993). In contrast to the numerous seeds of plants found in the aquatic zones of the chert (e.g., Allenbya, Keratosperma, Decodon), endocarps and twigs of Prunus are quite rare, suggesting that they were rafted in from outside the chert-producing wetlands. Prunus endocarps can be compared with those from Clarno (Manchester 1994) and Chinese endocarps of Eocene age ( $\mathrm{Li}$ et al. 2011). Woody twigs that Cevallos-Ferriz and Stockey named Prunus allenbyensis can be compared most closely with Eocene wood from 
Clarno and related sites (Wheeler and Manchester 2004).

A second intriguing occurrence at Princeton is of the numerous flowers of Paleorosa similkameenensis (Rosaceae; Basinger 1976b; Cevallos-Ferriz et al. 1993). Basinger (1976b) recognized the rosaceous morphology of these flowers. Based on additional specimens Cevallos-Ferriz et al. (1993) restudied Paleorosa and compared it most closely to Pyrecantha M. Roem. These authors noted similarities of fruit morphology with Spiraeoideae and pollen like that of some Maloideae. Evans and Campbell (2002) said of Paleorosa that it has "some similarities with Gillenia, Vauquelinia and some Maloideae" and suggested that Paleorosa provides evidence that Spiroiedeae could be related to the origin of Maloideae. These authors concluded that the distribution of extant taxa and the presence of Paleorosa support the North American origin of the subfamily Maloideae in contrast to the more commonly held view of an Asian origin (Evans and Campbell 2002).

Fossils of the Rosaceae are well known components of the Okanagan Highlands compression floras and have been reviewed for western North America by DeVore and Pigg (2007, 2009). Flowers of Prunus and Oemleria Rchb. (Benedict et al. 2011) and leaves with unusual asymmetry that resemble extant Sorbus hybrids have been described from Republic (DeVore and Pigg 2016).

\section{Rosids II Malvidae}

\section{Myrtales}

Lythraceae: Lythraceous fruits and seeds were described from the Princeton chert as Decodon allenbyensis (Cevallos-Ferriz and Stockey 1988b). Decodon seeds are pyramidal with a prominent gemination valve, and borne in a thin-walled capsule. A 
second, larger lythraceous fruit was noted but not described (Cevallos-Ferriz and Stockey 1988 b). Rhizomes with the characteristic secondary cortical tissues and wood of Decodon were later described (Little and Stockey 2003, 2005).

Modern Decodon verticillatus (L.) Elliott ("swamp loosestrife") is endemic to eastern North America where it grows as an aquatic perennial shrub that produces clumps or "islands" in swamps or shallow freshwater. Fossil Decodon and related forms are well known throughout the Northern Hemisphere, as recently reviewed by Grímsson et al. (2012).

Lythraceous leaves most similar to the Old World mangrove Duabanga were also described from the Princeton chert by Little et al. (2004) who did a survey of extant lythraceous leaf anatomical structure. Grímsson et al. (2012) described two sizes of Decodon pollen, from the matrix of the Princeton chert. Variability in pollen size within a single plant is a relatively common phenomenon among Lythraceae (Graham 2013). Extant and fossil Lythraceae have been well surveyed by Graham (2013). Additional analysis of floral, fruit and seed morphology within the family is currently underway in association with study of the Indian myrtalean Enigmocarpon Sahni (Manchester et al. 2015b).

Myrtaceae: Paleomyrtinaea allenbyensis seeds are a common component associated with the aquatic plants in the Princeton chert, where a few fruits were also found (Pigg et al. 1993). These fruits and seeds are quite similar to ones found in the late Paleocene Almont flora of North Dakota that were compared initially by Crane et al. (1990) to the guava genus Psidium L. and renamed Paleomyrtinaea sp. by Pigg et al. (1993). Fruits are leathery berries that contain numerous seeds. Seeds have a C-shaped 
embryo cavity that varies widely in appearance in section, depending on the plane of section. They have a prominent palisade outer layer and are composed primarily of parenchyma. Fruits identified as Paleomyrtinaea have been noted in the compression leaf flora at Republic (Wehr and Manchester 1996), and the late Paleocene upper Fort Union Formation (Wilf 1998; Wilf et al. 1998). Although it is difficult to equate permineralized fruits and compressions, they are of similar size and shape, and both have the characteristic numerous C-shaped seeds that one would expect.

Comparison of seed coat micromorphological features with those of extant Myrtaceae (Landrum and Sharp 1989) suggested that Paleomyrtinaea was more similar to the genus Mosiera Small; however, the lack of floral characters diagnostic at the level of genus precluded a close comparison (Pigg et al. 1993).

\section{Sapindales}

Sapindaceae: Wehrwolfea striata (Erwin and Stockey 1990) was described on the basis of 17 staminate flowers with in situ pollen. The genus was named in honor of the research team of Wolfe and Wehr, who produced the first monograph of the Republic, Washington flora (Wolfe and Wehr 1987). Both young, immature floral buds and mature flowers are known. The younger buds have perianth parts that overlap one another to enclose the stamens, whereas mature flowers are opened to reveal a flat receptacle bearing three sepals and up to four petals surrounding a rudimentary pistil. The pistil sits above an interstaminal disk. Pollen is borne in $10^{+}$stamens in two groups of unequal length. The pollen is prolate to subprolate with the smaller, immature pollen having a psilate outer surface, and the mature pollen is striate with a distinctive equatorial bridges. Wehrwolfea is most similar to plants of the tribe Dodonaeeae, including 
Dodonaea, the "hop-bush" (Erwin and Stockey 1990). Sapindaceae is well represented in the Okanagan Highlands compression flora by Koelreuteria Laxm., Dipteronia Oliv., Aesculus L. and several species of Acer (DeVore and Pigg 2009).

\section{Asterids}

Asterids are represented by endocarps of Diplopanax (Cornaceae) and several types of pollen grains that together are representative of Lamiales, Asterales (?), Apiales and Dipsacales (Stockey et al. 1998; Manchester et al. 2015a).

\section{Cornales}

Cornaceae: Diplopanax eydei is a fruit assignable to the modern tropical genus Diplopanax Hand.-Mazz., described from several specimens that show the distinctive morphology of this genus (Stockey et al. 1998). Whereas mastixioid cornalean endocarps are a common component, especially of European fossil floras, they are relatively rare in North American floras and have been difficult to relate directly with modern taxa. (Tiffney and Haggard 1996). It was possible to identify this Diplopanax because of the rare preservation of an outer fleshy valve that is characteristic of the genus (Stockey et al. 1998).

\section{Lamiales}

Oleaceae: Pollen of this family has been reported by Manchester et al. (2015a).

\section{Asterales (?)}

Asteraceae: Pollen of this family has been reported by Manchester et al. (2015a). However, it has not been verified by critically diagnostic pollen ultrastructural features.

\section{Apiales}

Araliaceae: Pollen similar to that of the genus Aralia L. has been reported by 
Manchester et al. (2015a).

\section{Dipsacales}

Caprifoliaceae: Pollen of this family similar to Viburnum has been reported by Manchester et al. (2015a).

\section{Incertae sedis}

Eorhiza arnoldii was described initially from a collection of rhizomes with attached leaf bases. Eorhiza has a narrow zone of secondary xylem and secondary phloem around its broad pith, surrounded by a broad cortex of aerenchymatous tissue (Fig, 1D). The narrow zone of wood has vessel elements with scalariform perforation plates, fiber tracheids and xylem parenchyma (Robison and Person 1973).

With many additional specimens at hand Stockey and Pigg (1994) resolved details of the sympodial branching system, axillary branches, adventitious roots and distinctive ensiform, unifacial leaves. Together these features were used to create the basis for the reconstruction of the plant's vegetative habit as a sympodial branching system of several orders of suboppositely produced axillary branches that become as large as or larger than their parent rhizome (Stockey and Pigg 1994). Occasionally, branches grow upright. Several types of fungi in its ground tissues, as noted by previous authors (Robison and Person 1973; Basinger and Rothwell 1977; Stockey and Pigg 1994), recently have been studied in detail (Klymiuk et al. 2013a, b; Klymiuk 2014).

Although its affinities are not yet understood, Eorhiza is a dominant member of the aquatic plant layers of the Princeton chert, and apparently it played a major role in the paleoecology of this flora. Based on its anatomical features and sympodial branching morphology Eorhiza fits into the Tomlinson model of growth architecture (Tomlinson 
1987; Stockey and Pigg 1994).

Princetonia allenbyensis is a second type of plant fossil with unknown taxonomic affinity. The name was given originally to a partially preserved flower of uncertain affinities (Stockey 1987). Later, additional specimens of inflorescences, flowers, mature and senescent fruits and numerous isolated seeds were determined to all represent the Princetonia plant (Stockey and Pigg 1991).

Princetonia is known from racemose infloresences with up to 13 small, helically arranged floral buds. Several specimens are known, all with buds borne on pedicels and found in varying stages of development (Stockey and Pigg 1991). Mature Princetonia flowers are around $4 \mathrm{~mm}$ long x $4.5 \mathrm{~mm}$ wide, actinomorphic, bisexual, with two sepals and four petals. They are borne on pedicels with a distinct anatomical structure that is common to flower buds, flowers and fruits, that allowed for the correlation of all stages of the flowering cycle from floral buds to senescent fruits. Up to 44 stamens are present, and filaments are laminar, with a short connective and elongate pollen sacs that tend to splay out separately into a "butterfly" in the matrix. The in situ pollen is elliptic, 5colpate and psilate (Stockey and Pigg 1991). The gynoecium is fused basally and free distally and has a lobed stigma, an elongate and solid style, an elongate ovary filled with numerous ovules, and axile placentation.

Fruits of Princetonia are 3-, 4-, or 5-loculate and loculicidal. They bear numerous irregularly shaped seeds per locule, attached to a prominent placental area. Seeds have a 2-layered seed coat with a prominent outer palisade layer and have a broad irregular "football" shape in the major plane and a narrow elliptic appearance in the minor plane. Seeds are anatropous and vascularized with a simple raphe. Some have internal contents 
that demonstrates they had perisperm, endosperm, a small embryo cavity and presumably, a tiny embryo.

With this combination of characters, affinities of Princetonia appear to be allied with Nymphaeaceae, Papaveraceae and the former Flacortiaceae (now Salicaceae, APG III). None of these families was an exact match, and Stockey and Pigg (1991) placed Princetonia in Magnoliidae sensu Cronquist.

The pollen type Pistillipollenites was first described from the Princeton chert by Boneham (1968), who noted this was the only type of angiosperm pollen he recovered. The genus was regarded as an excellent stratigraphic indicator of the middle Eocene, yet its taxonomic affinities remain unclear. Crepet and Daghlian (1981) described pollen of this type from flowers they placed in the Gentianaceae; however, highly similar pollen was then found in a flower with different morphological features from the Eocene of Horsefly, British Columbia that was named Pistillipollianthus wilsonii Stockey \& Manchester (Stockey and Manchester 1988). Whether all pollen of this type is identical, or whether there is some strong convergence from pollen of widely different genera, remains unclear.

\section{Discussion}

Significance of the floral components of the Princeton chert: The Princeton chert megafossils that can be assigned to modern genera include Osmunda, Pinus, Metasequoia, Saururus, Ampelocissus, Prunus, Decodon, Diplopanax, and ?Ribes. Of these, Pinus arnoldii and Metasequoia milleri are reconstructed as "whole plants" from multiple interconnected organs (Rothwell and Basinger 1979; Basinger 1981, 1984; Klymiuk et al. 2011). Dennsteadtiopsis, Trawetsia, Makotopteris, Dickwhitea, Allenbya, 
Keratosperma, Heleophyton, Soleredera, Uhlia, Ethela, Paleomyrtinaea, Paleorosa, Liriodendroxylon, and Wehrwolfea can be placed in modern families but have combinations of characters not seen in extant genera. Princetonia and Eorhiza cannot be placed in families and remain assigned to incertae sedis. Pistillipollenites pollen is found in at least two different flower types and its affinity or affinities remain unclear. It is rather common for an Eocene fossil plant assemblage to have a combination of taxa that include those that are 1) well known (to a modern genus), 2) known (to a modern family) and 3) unknown (incertae sedis). Such a pattern reflects the relative level of diversification in the evolutionary history of different plant groups during the Eocene.

Comparison with Okanagan compression floras: Within the Okanagan Highlands the major lacustrine leaf compression floras are at Republic, Washington and Princeton (Thomas Ranch and One Mile Creek), Quilchena, McAbee, Falklands, Horsefly and Driftwood Creek, BC (Greenwood et al. 2016). When comparing the Princeton chert flora with these relatively coeval compression floras, several factors are immediately apparent (Table 1). First, the compression floras are considerably more diverse taxonomically. Whereas the Princeton chert has a respectable permineralized flora of over 30 species, taxa in the compression flora at Republic, for example, number in the several hundreds.

Among conifers, only around three or four conifers are present in the Princeton chert, and all are pines except for the ubiquitous Asian swamp plant today, Metasequoia. In contrast, the Okanagan Highlands compression floras have a highly diverse conifer component that includes Abies Mill., Picea A. Dietr., Pseudolarix Gordon, Cunninghamia, R. Br., Sequoia Endl., Chamaecyparis Spach and Taxus L., among 
others. We see no megafossils in the Princeton chert of the many hardwood trees that are common in the compression floras, such as Alnus Mill., Betula L., Ulmus L., Tilia L., or Acer L. (DeVore and Pigg 2009). Presumably these plants would have been spatially removed from those preserved mostly within the in situ vegetation. In contrast, ferns and monocots appear to be more prominent in the Princeton chert floras, perhaps because 1) they are more likely to be found in situ in the aquatic to semiaquatic habitats represented by the chert and 2) they are more easily identified when they are found anatomically preserved (Collinson 2002).

Moveover, there are relatively few genera in common between compression and permineralized floras (e.g., Osmunda, Pinus, Metasequoia, Prunus, possibly Decodon and Paleomyrtinaea). Interestingly, Prunus endocarps and woody twigs have been recovered from the chert (Cevallos-Ferriz and Stockey 1990a), whereas flowers and leaves are known in compression floras where evidence of endocarps is equivocal (DeVore and Pigg 2007; Benedict et al. 2011). Some taxa, such as Paleomyrtinia and Decodon may be present in both preservational types (Pigg et al. 1993; Wehr and Manchester 1996), but it is difficult to reconcile these examples as equivalent because of the different characters that are preserved in each mode.

Considerably more families than genera are held in common in the chert and compression floras (Table 1). Nymphaeaceae is represented in the chert by Allenbya, in the Republic compression flora by Nuphar (DeVore et al. 2015). The unnamed flowers and fruits of Lauraceae occur in the Princeton chert, while Sassafras and other lauraceous leaves occur throughout the Okanagan Highlands leaf compression floras. Other families found in both types of localities include Magnoliaceae, Juncaceae/Cyperaceae, Vitaceae, 
Rosaceae, Sapindaceae, Cornaceae, and possibly Araceae, Alismataceae, and Grossulariaceae. There are relatively few families represented in the chert that are so far not known among compression floras. This is largely because genera such as Saururus may be difficult to identify as a compression and the various types of monocot and fern foliage may be present in the compression record but difficult to distinguish taxonomically.

\section{Comparison with other permineralized Eocene fruit and seed floras:}

Considerable information about the anatomy of Eocene plants is available also from several other permineralized floras, the best known of which are the Clarno Nut Beds of Oregon, Appian Way of Vancouver Island, the London Clay of the UK, and Messel in Germany (Manchester 1994; Atkinson et al. 2015 and references therein; Reid and Chandler 1933; Collinson 1984; and Collinson et al. 2012, respectively). Table 2 documents the common occurrence of families across the Princeton chert and these other four floras.

Of the 58 families recognized altogether from all the floras, only Lauraceae is common to all five localities, while Lythraceae, Vitaceae, and some type of palm occur in all but Appian Way, and Icacinaceae and Juglandaceae occur in all but the Princeton chert (Table 2). Eight families are found in three of the five floras: Magnoliaceae in Princeton /Messel/Clarno; Pinaceae, and Cornaceae in Princeton/ Clarno/London Clay, Nymphaeaceae/ales? in Princeton/Messel/London Clay, and Platanaceae in Messel/Clarno/Apian Way. Messel/Clarno/London Clay shared Anacardiaceae, Bursuraceae, and Menispermaceae (Table 2). Eighteen families co-occurred at only two localities and 37 were present only at a single locality with 13 being unique to the Princeton chert, 16 at Messel, 6 at Clarno, 0 in the London Clay and 3 at Appian Way. 
Conclusions: The work of the past forty years has yielded a considerable amount of information about the structure and taxonomic affinities of the Princeton chert plants. Much has been learned about the ecological roles of associated fungi. All of this work has laid a strong foundation for going further and learning more about the "whole plants" in the Princeton chert and to better understand the plant community structures in which they grew.

One very striking aspect of the floral composition of the Princeton chert is how common the rhizomatous plant habit is, as would be expected in an aquatic habitat. Eorhiza and the fern Dennsteadtiopsis are an excellent example of anatomical convergence with both having rhizomes with a broad parenchymatous pith, a relatively narrow cylinder of vascular tissue, and a broad cortex with aerenchymatous tissue, surrounded by a strong petiole or stipe (Fig. 1B,D). This dicot plant and fern share an aquatic plant habit that is also characteristic of many of the monocots, including three types of Alismatales, an iris-like form, and a plant related to Cyperaceae/Juncaceae. Other aquatic plants include the nymphaeacean Allenbya, the piperalean Sarururus, as well as the lythraceous aquatic plant Decodon.

Another intriguing aspect of the Princeton chert is the preservation of multiple stages in the life cycles for several plants. Princetonia, Saururus, Wehrwolfea and the unnamed lauraceous inflorescence are all known from both floral buds and mature flowers with young and developing pollen and, in some cases, flower and fruit, as well as ovules and mature seeds. The documentation of multiple reproductive structures for a particular plant provides not only a large number of taxonomic characters for comparison but also a sense of the sequence of developmental features of a plant that can be 
informative of its life history. Studies of this type are important also to understanding the actual biodiversity of the flora.

Among the most intriguing of the Princeton chert plants are Eorhiza and Princetonia. For some time an organic connection has been sought, unsuccessfully, between these two genera. There may be several reasons why this presumed connection has yet to be found. First, Eorhiza grows as an extensive sympodial rhizomatous system in situ within the matrix where it has been mapped (Stockey and Pigg 1994). Occasional upward-turning secondary or even tertiary branches may have borne fertile stalks; perhaps these were rare or delicate and simply not easily preserved. Another alternative is that the Eorhiza rhizomatous branching system might bear a different flower and fruit type. One possibility is the recently described Sarururus tuckerae, a plant whose modern counterpart grows today extensively along marginal aquatic zones. Stem anatomy, leaves and wood anatomical structure of extant Saururus bear some reasonable similarities to Eorhiza (Robison and Person 1973; Stockey and Pigg 1994; Carlquist et al. 1995;

Carlquist 2009, 2013; Isnard et al. 2012; Trueba 2015). A reassessment of these and some other Princeton chert plants in light of recent knowledge about phylogenies may help us better understand the plants that grew in this Eocene wetlands of the Okanagan Highlands and the paleoenvironment they represent.

\section{Acknowledgements}

We thank Ruth A. Stockey for her generosity and encouragement throughout our careers and are happy to be able to contribute to this special volume in her honor. We thank Ashley A. Klymiuk, Stefan A. Little and Selena Y. Smith for inviting our 
participation in this volume and Ashley A. Klymiuk, Steven R. Manchester and Peter Wilf for their help on references.

\section{References}

Arnold, C.A., and Daugherty, L.H. 1964. A fossil dennsteadtioid fern from the Eocene Clarno formation of Oregon. Contributions from the Museum of Paleontology, The University of Michigan, 19: 65-88.

Atkinson, B.A., Stockey, R.A., Rothwell, G.W., Mindell, R.A., Bolton, M. 2015. Lauraceous flowers from the Eocene of Vancouver Island: Tinaflora beardiae gen. et sp. nov. (Lauraceae). International Journal of Plant Sciences, 176: 567585.

Basinger, J.F. 1976a. Permineralized plants from the Eocene, Allenby Formation of southern British Columbia. M. Sc. thesis, Department of Botany, University of Alberta, Edmonton, Alberta.

Basinger, J.F. 1976b. Paleorosa similkameenensis, gen. et. sp. nov., permineralized flowers (Rosaceae) from the Eocene of British Columbia. Canadian Journal of Botany, 54: 2293-2305.

Basinger, J.F. 1979. Structurally preserved Metasequoia from the middle Eocene of southern British Columbia. Ph.D. Dissertation, Department of Botany, University of Alberta, Edmonton, Alberta.

Basinger, J.F. 1981. The vegetative body of Metasequoia milleri from the middle Eocene of southern British Columbia. Canadian Journal of Botany, 59: 2379-2410. 
Basinger, J.F. 1984. Seed cones of Metasequoia milleri from the middle Eocene of southern British Columbia. Canadian Journal of Botany, 62: 281-289.

Basinger, J.F. and Rothwell, G.W. 1977. Anatomically preserved plants from the middle Eocene Allenby Formation of British Columbia. Canadian Journal of Botany, 54: 1884-1990.

Benedict, J.C., DeVore, M.L., and Pigg., K.B. 2011. Prunus and Oemleria (Rosaceae) flowers from the late early Eocene Republic flora of northeastern Washington State, USA. International Journal of Plant Sciences, 172: 948-958.

Bjorholm, S.W., Svenning, J.-C., Baker, W.J., Skov, F., and Balslev, H. 2006. Historical legacies in the geographical diversity patterns of New World palm (Arecaceae) subfamilies. Botanical Journal of the Linnaean Society 151: 113-125.

Bomfleur B., Grimm, G.W., and McLoughlin, S. 2015. Osmunda pulchella sp. nov. from the Jurassic of Sweden--reconciling molecular and fossil evidence in the phylogeny of modern royal ferns (Osmundaceae). BMC (BioMed Central) Evolutionary Biology, 15: 1-26.

Boneham R.F. 1968. Palynology of three Tertiary coal basins in south-central British Columbia. Ph.D. Dissertation, University of Michigan, Ann Arbor, Michigan.

Carlquist, S. 2009. Xylem heterochromy: an unappreciated key of angiosperm origins and diversification. Botanical Journal of the Linnaean Society, 161: 26-65.

Carlquist, S. 2013. More woodiness/less woodiness: evolutionary avenues, ontogenetic mechanisms. International Journal of Plant Sciences, 174: 964-991.

Carlquist, S., Dauer, K., and Nishimure, S.Y. 1995. Wood and stem anatomy of Saururaceae with reference to ecology, phylogeny, and origin of the 
monocotyledons. IAWA (International Journal of Wood Anatomists) Journal, 16: 133-150.

Cevallos-Ferriz, S.R.S. 1987. Permineralized fruits and seeds from the middle Eocene Princeton chert locality, British Columbia, Canada. M. Sc. thesis, University of Alberta, Edmonton, Alberta.

Cevallos-Ferriz, S.R.S. 1990. Permineralized dicotyledonous remains from the middle Eocene Princeton chert locality, British Columbia: Magnoliaceae and Rosaceae. Ph.D. dissertation, University of Alberta, Edmonton, Alberta.

Cevallos-Ferriz, S.R.S. 1995. Fruits of Ribes from the Princeton chert, British Columbia, Canada. American Journal of Botany, 82 (supplement): 84.

Cevallos-Ferriz, S.R.S., and Stockey, R.A. 1988a. Permineralized fruits and seeds from the Princeton chert (middle Eocene) of British Columbia: Araceae. American Journal of Botany, 75: 1099-1113.

Cevallos-Ferriz, S.R.S., and Stockey, R.A. 1988b. Permineralized fruits and seeds from the Princeton chert (middle Eocene) of British Columbia: Lythraceae. Canadian Journal of Botany, 66: 303-312.

Cevallos-Ferriz, S.R.S., and Stockey, R.A. 1989. Permineralized fruits and seeds from the Princeton chert (middle Eocene) of British Columbia: Nymphaeaceae. Botanical Gazette 150: 207-217.

Cevallos-Ferriz, S.R.S., and Stockey, R.A. 1990a. Vegetative remains of the Rosaceae from the Princeton chert (middle Eocene) of British Columbia. IAWA (International Journal of Wood Anatomists) Bulletin n. s., 11: 261-280. 
Cevallos-Ferriz, S.R.S., and Stockey, R.A. 1990b. Vegetative remains of the Magnoliaceae from the Princeton chert (middle Eocene) of British Columbia. Canadian Journal of Botany, 68: 1327-1339.

Cevallos-Ferriz, S.R.S., and Stockey, R.A. 1990c. Permineralized fruits and seeds from the Princeton chert (middle Eocene) of British Columbia: Vitaceae. Canadian Journal of Botany, 68: 288-379.

Cevallos-Ferriz, S.R.S., and Stockey, R.A. 1991. Permineralized fruits and seeds from the Princeton chert (middle Eocene) of British Columbia: Rosaceae (Prunoideae). Botanical Gazette, 152: 369-379.

Cevallos-Ferriz, S.R.S., Erwin, D.M., and Stockey, R.A. 1993. Further observations on Paleorosa similkameenensis (Rosaceae) from the middle Eocene Princeton chert of British Columbia, Canada. Review of Palaeobotany and Palynology, 78: 277291.

Cevallos-Ferriz, S.R.S., Stockey, R.A., and Pigg, K.B. 1991. The Princeton chert: evidence for in situ aquatic plants. Review of Palaeobotany and Palynology, 70: 173-185.

Chen, I., and Manchester, S.R. 2007. Seed morphology of modern and fossil Ampelocissus (Vitaceae) and implications for phytogeography. American Journal of Botany, 94: 1534-1553.

Cohen, K., and Gibbard, P.L. 2015. ICS International chronostratigraphic chart. http://www.stratigraphy.org/ICSchart/ChronostratChart2015-01.jpg, accessed January 2016.

Collinson, M.E. 1980. Recent and Tertiary seeds of the Nymphaeaceae sensu lato with a 
revision of Brasenia ovula (Brong.) Reid and Chandler. Annals of Botany, 46: 603-632.

Collinson, M.E. 1984. Fossil plants of the London Clay. Field guide to fossils. Number 1. The Palaeontological Association. London.

Collinson, M.E. 2001. Cainozoic ferns and their distribution. Brittonia, 53:173-235.

Collinson, M.E. 2002. The ecology of Cainozoic ferns. Review of Palaeobotany and Palynology, 119: 51-68.

Collinson, M.E., Manchester, S.R., and Wilde, V. 2012. Fossil fruits and seeds of the middle Eocene Messel biota, Germany. Abhandlungen der Senckenberg Gesellschaft für Naturforschung, Band 570. Frankfort.

Crane, P.R., Manchester, S.R., and Dilcher, D.L. 1990. A preliminary survey of fossil leaves and well-preserved reproductive structures from the Sentinel Butte Formation (Paleocene) near Almont, North Dakota. Fieldiana Geology, NS, 20: 1-63.

Cranfill, R., and Kato, M. 2003. Phylogenetics, biogeography, and classification of the woodwardioid ferns (Blechnaceae), p. 25-48 in S. Chandra and M. Strivastava, eds. Pteridology in the new millennium, Kluwer, Dorddrecht.

Crepet, W.L., and Daghlian, C.P. 1981. Lower Eocene and Paleocene Gentianaceae: floral and palynological evidence. Science, 214: 75-77.

Currah R.S., and Stockey, R.A. 1991. A fossil smut fungus from the anthers of an Eocene angiosperm. Nature, 350: 698-699.

Currah, R.S., Stockey, R.A., and LePage, B.A. 1998. An Eocene tar spot on a fossil palm and its fungal hyperparasite. Mycologia, 90: 667-673. 
Cuismano, N., Bogner, J., Mayo, S.J., Boyce, P.C.,Wong, S.Y., Hesse, M.. Hetterscheid, W.L.A., Keating, R.C., and French, J.C. 2011. Relationships within the Araceae: Comparison of morphological patterns with molecular phylogenies. American Journal of Botany, 98: 654-668.

Czaja, A.D., Kudryavtsev, A.B., Cody, G.D., and Schopf, J.W. 2009. Characterization of permineralized kerogen from an Eocene fossil fern. Organic Geochemistry, 40: 353-364.

Daghlian, C.P. 1981. A review of the fossil record of monocotyledons. Botanical Review, 47: 517-555.

DeVore, M.L., and Pigg, K.B. 2007. A brief review of the fossil history of the family Rosaceae with a focus on the Eocene Okanogan Highlands of eastern Washington State, USA, and British Columbia, Canada. Plant Systematics \& Evolution, 266: 45-57.

DeVore, M.L., and Pigg, K.B. 2009. Floristic composition and transitions of middle Eocene to late Eocene and Oligocene floras in North America. Bulletin of Geosciences, 85: 111-134.

DeVore, M.L., and Pigg, K.B. 2016. Biotic processes in the Okanagan Highlands floras: possible evidence of hybridization in plants adapting to a temperate forest. Canadian Journal of Earth Sciences, 53: 622-629.

DeVore, M.L., Taylor, W., and Pigg, K.B. 2015. Nuphar carlquistii sp. nov., (Nymphaeaceae): A water lily from the latest early Eocene, Republic, Washington, USA. International Journal of Plant Sciences, 176: 365-377. 
Doyle, J.A., and Endress, P.K. 2010. Integrating Early Cretaceous fossils into the phylogeny of living angiosperms: Magnoliidae and eudicots. Journal of Systematics and Evolution, 48: 1-35.

Endress, P.K. 2008. Perianth biology in the basal grade of extant angiosperms. International Journal of Plant Sciences, 169: 844-862.

Erwin, D.M. 1991. Permineralized monocotyledons from the middle Eocene Princeton chert locality, British Columbia, Canada. Ph.D. dissertation, University of Alberta, Edmonton, Alberta.

Erwin, D.M., and Schorn, H.E. 2006. Pinus baileyi (section Pinus, Pinaceae) from the Paleogene of Idaho, USA. American Journal of Botany, 93: 197-205.

Erwin, D.M., and Stockey, R.A. 1989. Permineralized monocotyledons from the middle Eocene Princeton chert (Allenby Formation) of British Columbia: Alismataceae. Canadian Journal of Botany, 67: 2636-2645.

Erwin, D.M., and Stockey, R.A. 1990. Sapindaceous flowers from the middle Eocene Princeton chert (Allenby Formation) of British Columbia, Canada. Canadian Journal of Botany, 68: 2025-2034.

Erwin, D.M., and Stockey, R.A. 1991a. Silicified monocotyledons from the middle Eocene Princeton chert (Allenby Formation) of British Columbia, Canada. Review of Palaeobotany and Palynology, 70: 147-162.

Erwin, D.M., and Stockey, R.A. 1991b. Soleredera rhizomorpha gen. et sp. nov., a permineralized monocotyledon from the middle Eocene Princeton chert of British Columbia, Canada. Botanical Gazette, 152: 231-247. 
Erwin, D.M., and Stockey, R.A. 1992. Vegetative body of a permineralized monocotyledon from the middle Eocene Princeton chert of British Columbia. Courier Forschungsinstitut Senckenberg, 147: 309-327.

Erwin, D.M., and Stockey, R.A. 1994. Permineralized monocotyledons from the middle Eocene Princeton chert (Allenby Formation) of British Columbia: Arecaceae. Palaeontographica Abteilung B, 234: 19-40.

Evans, R.C. and Campbell, C.S. 2002. The origin of the apple subfamily (Maloideae; Rosaceae) is clarified by DNA sequence data from duplicated GBSSI genes. American Journal of Botany, 89: 1478-1484.

Ferguson, D.K., Zetter, R., and Paudayal, K.N. 2007. The need for the SEM in palaeopalynology. Compte Rendus Paleo. 6: 423-430.

Gandolfo, M.A., Nixon, K.C., and Crepet,W.L. 2004. Cretaceous flowers of Nymphaeaceae and implications for complex insect entrapment pollination mechanism in early angiosperms. Proceedings of the National Academy of Sciences USA, 101: 8056-8060.

Gernandt, D.S., López, G.G., García, S.O., and Liston, A. 2005. Phylogeny and classification of Pinus. Taxon, 54: 29-42.

Gernandt, D.S., Magallón, S., López, G.G, Flores, L., Willyard, A. and Liston, A. 2008. Use of simultaneous analyses to guide fossil-based calibrations of Pinaceae phylogeny. International Journal of Plant Sciences, 169: 1086-1099.

Goldblatt, P., Le Thomas, A. 1997. Pollen morphology of Madagascan Aristea and Geosiris (Iridaceae-Nivenioideae) in relation to systematics and phylogeny. 
Bulletin du Muséum national d'histoire naturelle Paris 4e séries, section B. Adansonia, 2: 223-233.

Goldblatt, P., Le Thomas, A., and Suárez-Cervera, M. 2004. Phylogeny of the AfroMadagascan Aristea (Iridaceae) revisited in the light of new data on pollen morphology. Botanical Journal of the Linnaean Society, 144: 41-68.

Graham, S.A. 2013. Fossil records in the Lythraceae. Botanical Review, 79: 48-145. Greenwood, D.R., Pigg, K.B., Basinger, J.F., and DeVore, M.L. 2016. A review of paleobotanical studies of the early Eocene Okanagan (Okanogan) Highlands floras of British Columbia, Canada and Washington, USA. Canadian Journal of Earth Sciences, 53: 548-564.

Grímsson, F., Ferguson, D.K., and Zetter, R. 2012. Morphological trends in the fossil pollen of Decodon and the paleobiogeographic history of the genus. International Journal of Plant Sciences, 173: 297-317.

Grímsson, F., Zetter, R., Halbritter, H. Grimm, G.W. 2014. Aponogeton pollen from the Cretaceous and Paleogene of North America and West Greenland: Implications for the origin and palaeobiogeography of the genus. Review of Palaeobotany and Palynology, 200: 161-187.

Hesse, M., and Zetter, R. 2005. Ultrastructure and diversity of recent and fossil zonaaperturate pollen grains. Plant Systematics \& Evolution, 255: 145-176.

Hesse, M., and Zetter, R. 2007. The fossil pollen record of Araceae. Plant Systematics \& Evolution, 263: 93-115. 
Hills, L.V., and Baadsgaard, H. 1967. Potassium-argon dating of some lower Tertiary strata in British Columbia. Bulletin of Canadian Petroleum Geology, 15: 138149.

Ickert, R.B., Thorkelson, D.J., Marshall, D.D., and Ullrich, T.D. 2009. Eocene adakitic volcanism in southern British Columbia: remelting of arc basalt above a slab window. Tectonophysics, 464: 164-185.

Iles, W.J.D., Smith, S.Y.,Gandolfo, M.A., and Graham, S.W. 2015. check date Invited review: Monocot fossils suitable for molecular dating analyses. Botanical Journal of the Linnaean Society, 178: 346-374.

InsideWood. 2004-onwards. Published on the Internet. http://insidewood.lib.ncsu.edu/search [accessioned 25 February, 2016 ].

Isnard, S., Prosperi, J., Wanke, S., Wagner, S.T., Samain, M.-S.,Truba, S.S., Frenzke, L., Neinhuis, C., and Rowe, N.P. 2012. Growth form evolution in Piperales and its relevance for understanding angiosperm diversification: an integrative approach combining plant architecture, anatomy, and biomechanics. International Journal of Plant Sciences, 173: 610-639.

Joy, K.W., Willis, A.J., and Lacey, W.S. 1956. A rapid cellulose peel technique in palaeobotany. Annals of Botany, New Series, 20: 635-637.

Karafit, S.J., Rothwell, G.W., Stockey, R.A., and Nishida, H. 2006. Evidence for sympodial vascular architecture in a filicalean fern rhizome: Dickwhitea allenbyensis gen. et sp. nov. (Athyriaceae). International Journal of Plant Sciences, 167: 721-727. 
Klymiuk, A.A. 2014. Paleomycology of the Princeton chert. Geological Society of America, Vancouver, B.C., Canada. Paper no. 199-6.

Klymiuk, A.A. 2016. Paleomycology of the Princeton Chert. III. Dictyosporic microfungi, Monodictysporites princetonensis gen. et sp. nov., associated with decayed rhizomes of an Eocene semi-aquatic fern. Mycologica, in press.

Klymiuk, A.A., Stockey, R.A., and Rothwell, G.W. 2011. The first organismal concept for an extinct species of Pinaceae: Pinus arnoldii Miller. International Journal of Plant Sciences, 172: 294-313.

Klymiuk, A.A., Taylor, T.N., Taylor, E.L., and Krings, M. 2013a. Paleomycology of the Princeton chert. I. Saprotrophic hyphomycetes associated with an Eocene angiosperm, Eorhiza arnoldii. Mycologia,105: 521-529.

Klymiuk, A.A., Taylor, T.N., Taylor, E.L., and Krings, M. 2013b. Paleomycology of the Princeton chert. II. Dark septate fungi in the aquatic angiosperm Eorhiza arnoldii indicate a diverse assemblage of root-colonizing fungi during the Eocene. Mycologia, 105: 1100-1109.

Landrum, L.R., and Sharp,W.P. 1989. Seed coat characters of some American Myrtinae (Myrtaceae): Psidium and related genera. Systematic Botany, 14: 370-376.

LePage, B.A., Currah, R. S., and Stockey, R.A. 1994. The fossil fungi of the Princeton chert. International Journal of Plant Sciences, 155: 822-830.

LePage, B.A., Currah, R.S., Stockey, R.A., and Rothwell, G.W. 1997. Fossil ectomycorrhizae from the middle Eocene. American Journal of Botany, 84: 410412. 
Les, D.H., Garvin, D.K., Wimpee, C.F. 1991. Molecular evolutionary history of ancient acquatic angiosperms. Proceedings of the National Academy of Sciences, USA, 88: 10119-10123.

Les, D.H., Schneider, E.L., Soltis, P.S., Soltis, D.E., Zanis M.1999. Phylogeny, classification and floral evolution of water lilies (Nymphaeaceae; Nymphaeales): a synthesis of non-molecular, rbcL, matK, and $18 \mathrm{~S}$ rDNA data. Systematic Botany, 24: 28-46.

Li, Y., Smith, T., Liu, C-J., Awasthi, N., Yang, J., Wang, Y.-F., and Li C.-S. 2011. Endocarps of Prunus (Rosaceae: Prunoideae) from the early Eocene of Wutu, Shandong Province, China. Taxon, 60: 555-564.

Little, S.A. 2006. The importance of whole plant reconstructions: morphology and anatomy of Lythraceae and Lauraceae from the Princeton chert. Ph.D. dissertation. University of Alberta, Edmonton, Alberta, Canada.

Little, S.A., and Stockey, R.A. 2003. Vegetative growth of Decodon allenbyensis (Lythraceae) from the middle Eocene Princeton chert with anatomical comparisons to Decodon verticillatus. International Journal of Plant Sciences, 164: 454-469.

Little, S.A., and Stockey, R.A. 2005. Morphogenesis of the specialized peridermal tissues in Decodon allenbyensis from the middle Eocene Princeton chert. IAWA (International Association of Wood Anatomists) Bulletin, 27: 73-87.

Little, S.A., Stockey, R.A., and Keating, R.C. 2004. Duabanga-like leaves from the middle Eocene Princton chert and comparative leaf histology of Lythraceae sensu lato. American Journal of Botany, 91: 1126-1139. 
Little, S.A., Stockey, R.A., Penner, B. 2009. Anatomy and development of fruits of Lauraceae from the middle Eocene Princeton Chert. American Journal of Botany, 96: $637-651$.

Liu, Xiu-Qun Liu, Ickert-Bond, S.M., Nie, Ze-Long, Zhou, Zhou, Chen, · Long-Qing and Wen, J. 2016. Phylogeny of the Ampelocissus-Vitis clade in Vitaceae supports the New World origin of the grape genus. Molecular Phylogenetics and Evolution, 95: $217-228$.

Manchester, S. R. 1994. Fruits and seeds of the Middle Eocene Nut Beds flora, Clarno Formation, Oregon. Palaeontographica Americana, 58: 1-205.

Manchester, S.R., Kapgate, D.K., and Wen, J. 2013. Oldest fruits of the grape family (Vitaceae) from the Late Cretaceous Deccan cherts of India. American Journal of Botany, 100: 1849-1859.

Manchester, S. R., Grimsson, F., and Zetter, R. 2015a. Assessing the fossil record of asterids in the context of our current phylogenetic framework. Annals of the Missouri Botanical Garden, 100: 329-363.

Manchester, S.R., Kapgate, D., Smith, S.Y., Pigg, K.B., and Graham, S. 2015 b. Systemaic affinities of Enigmocarpon (Myrtales) from the Late Cretaceous of India. Botany 2015, Abstract 1242.

Massoni, H., Doyle, J. and Sauquet, H. 2015. Fossil calibration of Magnoliidae, an ancient lineage of angiosperms. Palaeontologia Electronica, 18:1.2FC, 1-25. McIver, E.E., and Basinger, J.F. 1993. Flora of the Ravenscrag Formation (Paleocene), southwestern Saskatchewan, Canada. Palaeontographica Canadiana, 10: 1-167. 
McMechan, R.D. 1983. Geology of the Princeton Basin. Paper 1983-3. Province of British Columbia, Ministry of Energy, Mines and Petroleum Resources. Victoria, British Columbia, November, 1983.

Metzgar, J.S., Skog, J.E., Zimmer, E.A., and Pryer, K.M. 2008. The paraphyly of Osmunda is confirmed by phylogenetic analyses of seven plastid loci. Systematic Botany, 33: 31-36.

Miller, C.N., Jr. 1971. Evolution of the fern family Osmundaceae based on anatomical studies. Contributions to the University of Michigan Museum of Paleontology, University of Michigan 23: 105-169.

Miller, C.N., Jr. 1973. Silicified cones and vegetative remains of Pinus from the Eocene of British Columbia. Contributions to the University of Michigan Museum of Paleontology, University of Michigan, 24: 101-118.

Moseley, M. F., Schneider, E.L., and Williamson, P.S. 1993. Phylogenetic interpretations from selected floral vasculature characters in the Nymphaeaceae sensu lato. Aquatic Botany 44: 325-342.

Mustoe, G.E. 2011. Cyclic sedimentation in the Eocene Allenby Formation of south-c Eocene to late Eocene and Oligocene floras in North America. Bulletin of Geosciences, 85: 111-134.

Nambudiri E.M.V., and Tidwell, W. D. 1998. Palmoxylon hebbertii, from the Lower Oligocene Golden Ranch Formation of central Utah, U.S.A., with an analysis of some characteristics previously used in the classification of Palmoxylon. Canadian Journal of Botany, 76: 517-529. 
Phipps, C.J., Osborn, J.M., and Stockey, R.A. 1995. Pinus pollen cones from the middle Eocene Princeton chert (Allenby Formation) of British Columbia, Canada. International Journal of Plant Sciences, 156: 117-124.

Pigg, K.B., and Rothwell, G.W. 2001. Anatomically preserved Woodwardia virginica (Blechnaceae) and a new filicalean fern from the middle Miocene Yakima Canyon flora of central Washington, USA. American Journal of Botany, 88: 777-787.

Pigg, K.B., and Stockey, R.A. 1996. The significance of the Princeton chert permineralized flora to the Middle Eocene upland biota of the Okanogan Highlands. Washington Geology, 24: 32-36.

Pigg, K.B., Stockey, R.A., and Maxwell, S.L. 1993. Paleomyrtinaea princetonensis gen. et sp. nov., permineralized myrtaceous fruits and seeds from the Princeton chert and related Myrtaceae from Almont, North Dakota. Canadian Journal of Botany, 71: $1-9$.

Prakash, U., Brezinova D., and Buzek.C. 1971. Fossil woods from the Doupovske Hory and Ceske Stredohori Mountains in northern Bohemia. Palaeontographica, 133B: $103-128$.

Read, P.B. 2000. Geology and industrial minerals in the Tertiary basins, south-central British Columbia. British Columbia Ministry of Energy, Mines, and Petroleum Resources Geofile 2000-2. British Columbia Ministry of Energy, Mines and Petroleum Resources, Victoria.

Reid, E.M., and Chandler, M.E. 1933. Flora of the London Clay. British Museum of Natural History, London. 
Robison, C.R., and Person, C.P. 1973. A silicified semiaquatic dicotyledon from the Eocene Allenby Formation of British Columbia. Canadian Journal of Botany, 51: $1373-1377$.

Romanov, M.S. and Dilcher, D.L. 2013. Fruit structure in Magnoliaceae s.l. and Archaeanthus and their relationships. American Journal of Botany, 100: 14941508.

Rothwell, G.W., and Basinger, J.F. 1979. Metasequoia milleri n. sp., anatomically preserved pollen cones from the middle Eocene (Allenby Formation) of British Columbia. Canadian Journal of Botany, 57: 958-970.

Russel, L.S. 1935. A Middle Eocene mammal from British Columbia. American Journal of Science, 291: 54-55.

Schorn, H.E., and Wehr, W. 1996. The conifer flora from the Eocene uplands at Republic, Washington. Washington Geology 24: 22-24.

Serbet, R., and Rothwell, G.W., 2003. Anatomically preseved ferns from the late Cretaceous of western North America: Dennstaedtiaceae. International Journal of Plant Sciences, 164: 1041-1051.

Smith, S.Y. 2007. Morphology, anatomy, and phylogeny of fossil and extant Saururaceae: insights from the Middle Eocene Princeton chert. Ph.D. dissertation, University of Alberta, Edmonton, Alberta.

Smith, S.Y. 2013. The fossil record of noncommelinid monocots. p. 29-59. In Early events in monocot evolution. P. Wilkin, S. J. Mayo, editors. Systematics Association Special Volume Series, Cambridge University Press. 
Smith, S.Y., and Stockey, R.A. 2003. Aroid seeds from the middle Eocene Princeton chert (Keratosperma allenbyense, Araceae): comparisons with extant Lasioideae. International Journal of Plant Sciences, 164: 239-250.

Smith, S.Y., and Stockey, R.A. 2007a. Establishing a fossil record for the perianthless Piperales: Saururus tuckerae sp. nov. (Saururaceae) from the middle Eocene Princeton chert. American Journal of Botany, 94: 1642-1657.

Smith, S.Y., and Stockey, R.A. 2007b. Pollen morphology and ultrastructure of Saururaceae. Grana, 46: 250-267.

Smith, S.Y., Collinson, M.E., Rudall, P.J., Simpson, D.A., Marone, F., and Stampanoni, M. 2009. Virtual taphonomy using synchrotron tomographic microscopy reveals cryptic features and internal structure of modern and fossil plants. Proceedings of the National Academy of Sciences, 106: 12013-12018.

Smith, S.Y., Stockey, R.A., Nishida, H. and Rothwell, G.W. 2006. Trawetsia princetonensis gen. et sp. nov. (Blechnaceae): a permineralized fern from the middle Eocene Princeton chert. International Journal of Plant Sciences, 167: 711719.

Stevens, P. F. (2001 onwards). Angiosperm Phylogeny Website. Version 12, July 2012 [and more or less continuously updated since]. http://www.mobot.org/MOBOT/research/APweb/ [accessed 15 January 2016].

Stockey, R.A. 1984. Middle Eocene Pinus remains from British Columbia. Botanical Gazette, 145: 262-274.

Stockey, R.A. 1987. A permineralized flower from the middle Eocene of British Columbia. American Journal of Botany, 74: 1878-1887. 
Stockey, R.A. 2002. Princeton chert. p. 359-362 in D.H. Briggs, ed. Palaeobiology II, Blackwell Science, Oxford.

Stockey, R.A. 2006. The fossil record of basal monocots. Aliso, 22: 91-106.

Stockey, R.A., and Manchester, S.R. 1988. A fossil flower with in situ Pistillipollenites from the Eocene of British Columbia. Canadian Journal of Botany, 66: 313-318.

Stockey, R.A., and Pigg, K.B. 1991. Flowers and fruits of Princetonia allenbyensis (Magnoliopsida: family indet.) from the middle Eocene Princeton chert of British Columbia. Reivew of Palaeobotany and Palynology, 70: 163-172.

Stockey, R.A., and Pigg, K.B. 1994. Vegetative growth of Eorhiza arnoldii Robison and Person from the middle Eocene Princeton chert locality of British Columbia. International Journal of Plant Sciences, 155: 606-616.

Stockey, R.A., and Wehr, W.C. 1996. Flowering plants in and around Eocene lakes of the Interior. p. 234-247 in R. Ludvigsen, ed. Life in stone: a natural history of British Columbia's fossils, UBC Press, Vancouver.

Stockey, R.A., LePage, B.A., and Pigg, K.B. 1998. Permineralized fruits of Diplopanax (Cornaceae, Mastixioideae) from the middle Eocene Princeton chert of British Columbia. Review of Palaeobotany and Palynology, 103: 223-234.

Stockey, R.A., Nishida, H. and Rothwell, G.W. 1999. Permineralized ferns from the middle Eocene Princeton chert. I. Makotopteris princetonensis gen. et sp. nov. (Athyriaceae). International Journal of Plant Sciences, 160: 1047-1055.

Stockey, R.A., Rothwell, G.W., Addy, H.D., and Currah, R.S. 2001. Mycorrhizal association of the extinct conifer Metasequoia milleri. Mycological Research, 105: 202-205. 
Thomas, R., and De Franceschi, D. 2013. Palm stem anatomy and computer-aided identification: The Coryphoideae (Arecaceae). American Journal of Botany, 100: 289-313.

Tiffney, B.H., and Haggard, K. K. 1996. Fruits of Mastixioideae (Cornaceae) from the Paleogene of western North America. Review of Palaeobotany and Palynology, 92: $29-54$.

Tomlinson, P.B. 1987. Architecture of tropical plants. Annual Review of Ecology and Systematics, 18: 1-21.

Town of Princeton, BC. 2016. http://www.princeton.ca/, [accessed May 2016].

Trueba, S., Rowe, N.P., Neinhuis, C., Wanke, S., Wagner, S.T., and Isnard, S. 2015. Stem anatomy and the evolution of woodiness in Piperales. International Journal of Plant Sciences, 176: 468-485.

Vavrek, M.J., Stockey, R.A., and Rothwell, G.W. 2006. Osmunda vancouverensis sp. nov. (Osmundaceae), permineralized fertile frond segments from the Lower Cretaceous of British Columbia, Canada. International Journal of Plant Sciences 167: $631-637$.

Wehr, W., and Manchester, S.R. 1996. Paleobotanical significance of Eocene flowers, fruits, and seeds from Republic, Washington. Washington Geology 24: 25-27. Wheeler, E.A. 2011. InsideWood - a web resource for hardwood anatomy. IAWA (International Association of Wood Anatomists) Journal, 32: 199-211.

Wheeler, E.A., and LaPasha. C. A. 1994. Woods of the Vitaceae--fossil and modern. Review of Palaeobotany and Palynology, 89: 175-207. 
Wheeler, E.A., and Manchester, S.R. 2004. Woods of the Eocene Nut Beds Flora, Clarno Formation, Oregon, USA. IAWA (International Association of Wood Anatomists) Journal, Supplement 3.

Wilf, P. 1998. Using fossil plants to understand global change: Evidence for PaleoceneEocene warming in the greater Green River Basin of southwestern Wyoming. Doctoral dissertation, University of Pennsylvania, Philadelphia.

Wilf, P., Beard, K.C., Davies-Vollum, K.S., and Norejko, J.W. 1998. Portrait of a late Paleocene (early Clarkforkian) terrestrial ecosystem: Big Multi Quarry and associated strata, Washakie Basin, southwestern Wyoming. Palaios, 13: 514-532.

Wilson, M.V.H. 1980. Eocene lake environments: depth and distance-from-shore variation in fish, insect, and plant assemblages. Palaeogeography, Palaeoclimatology and Palaeoecology, 32: 21-44.

Wilson, M.V.H. 1982. A new speies of Amia from the Middle Eocene of British Columbia. Palaeontology, 25: 413-424.

Wolfe, J.A., and Wehr W. 1987. Middle Eocene dicotyledonous plants from Republic, northeastern Washington. United States Geological Survey Bulletin 1597, 1-25.

Wu, C.-H. and Kubitzki, K. 1993. Saururaceae. p. 586-588 in K. Kubitzki, J. G. Rohwer and V. Bittrich eds. The families and genera of vascular plants, vol. II. Flowering plants. Dicotyledons: magnoliid, hamamelid and caryophyllid families, SpringerVerlag, Berlin.

Xu, Xiao-Hui, Wang, Zi-Xi, Yang, Guo-Lin, Wang, Jin, Yan, Yi, Ma, Fu-jun, Wang, Qui. 2015. Two Pinus species from the Upper Miocene in Zhejiang, China and 
their palaeobiogeographic significance. Review of Palaeobotany and Palynology, 215: 68-75. 
Table 1. Princeton chert plants in relation to Okanagan Highlands compression taxa. *Genera based on Princeton chert type specimens. Data from this paper and DeVore and Pigg 2009.

Family Princeton chert plant Related compression taxon

\begin{tabular}{|c|c|c|}
\hline Osmundaceae & Osmunda sp. & Osmunda \\
\hline Dennstaedtiaceae & Dennstaedtiopsis & $-?-$ \\
\hline Blechnaceae & Trawetsia* & - \\
\hline \multirow[t]{2}{*}{ Athyriaceae } & Makotopteris* & -- \\
\hline & Dickwhitea * & -- \\
\hline Pinaceae & Pinus & Pinus \\
\hline Cupressaceae & Metasequoia & Metasequoia \\
\hline Nymphaeaceae & Allenbya* & Nuphar \\
\hline Magnoliaceae & Liriodendroxylon & Magnolia \\
\hline Lauraceae & Unnamed taxon & Sassafras, Phoebe \\
\hline Saururaceae & Saurura & -- \\
\hline Araceae & Keratosperma* & foliage? \\
\hline Alismataceae & Heleophyton* & foliage? \\
\hline Liliales & Soleredera* & -- \\
\hline Arecaceae & Uhlia* & -- \\
\hline \multicolumn{2}{|c|}{ Juncaceae/Cyperaceae Ethela* } & Cyperaceae \\
\hline Grossulariaceae & Ribes sp. (?) & Ribes \\
\hline
\end{tabular}




\begin{tabular}{lll} 
Family & Princeton chert plant & Related compression taxon \\
\hline Vitaceae & Ampelocissus & Vitis \\
Rosaceae & Paleorosa* & $--?-$ \\
\multicolumn{1}{c}{ Prunus } & Prunus \\
Lythraceae & Decodon & Decodon-like \\
Myrtaceae & Paleomyrtinaea & Paleomyrtinaea \\
Sapindaceae & Wehrwolfea* & Acer, Dipteronia, Koelreuteria \\
Cornaceae & Diplopanax & Cornus \\
Incertae sedis & Eorhiza & - -?--
\end{tabular}


https://mc06.manuscriptcentral.com/botany-pubs 
Table 2. Comparison of Princeton chert taxa with those of other Eocene localities with anatomically preserved floras. Families common to all five localities in black, to four localities in red, three localities in blue, two localities in green and at a single locality in yellow. (Data from: This paper; Collinson et al., 2012; Manchester 1994; Reid and Chandler 1933; Collinson 1984; Atkinson et al. 2015)

\begin{tabular}{|c|c|c|c|c|c|}
\hline Taxon/Family & $\begin{array}{c}\text { Princeton } \\
\text { chert }\end{array}$ & Messel & $\begin{array}{c}\text { Clarno } \\
\text { Nut beds }\end{array}$ & $\begin{array}{c}\text { London } \\
\text { Clay }\end{array}$ & $\begin{array}{c}\text { Appian } \\
\text { Way }\end{array}$ \\
\hline LeafyLiverwort & & & & & $\bar{x}$ \\
\hline Athyriaceae & $\mathrm{x}$ & & & & \\
\hline Blechnaceae & $\mathrm{x}$ & & & & \\
\hline Dennsteadtiaceae & $\mathrm{x}$ & & & & \\
\hline Gleicheniaceae & & & & & $\mathrm{x}$ \\
\hline Osmundaceae & $\mathrm{x}$ & & & & \\
\hline Schizeaceae & & & & & $\mathrm{x}$ \\
\hline Cupressaceae & $\bar{x}$ & & & & $\bar{x}$ \\
\hline Doliastrobaceae & & $\mathrm{x}$ & & & \\
\hline Pinaceae & $\mathrm{x}$ & & $\mathrm{x}$ & $\mathrm{x}$ & \\
\hline Taxaceae & & & $\mathrm{x}$ & & \\
\hline Actinidiaceae & & & $\bar{x}$ & $\mathrm{x}$ & \\
\hline Alangiaceae & & $\bar{x}$ & $\mathrm{x}$ & & \\
\hline Alismataeae & $\mathrm{x}$ & & & & \\
\hline Altingiaceae & & $\mathrm{x}$ & & & \\
\hline Taxon/Family & Princeton & Messel & Clarno & London & Appian \\
\hline
\end{tabular}




\begin{tabular}{|c|c|c|c|c|c|}
\hline & chert & & Nutbeds & Clay & Way \\
\hline Anacardiaceae & & $\mathrm{x}$ & $\mathrm{x}$ & $\mathrm{x}$ & \\
\hline Annonaceae & & & $\mathrm{x}$ & $\mathrm{x}$ & \\
\hline Apocynaceae & & $\mathrm{x}$ & & & \\
\hline Apotogetonaceae & $\mathrm{X}$ & & & & \\
\hline Araceae & $\mathrm{x}$ & & & & \\
\hline Araliaceae & $\mathrm{x}$ & & $\mathrm{x}$ & & \\
\hline Arecaceae & $\mathrm{x}$ & $\mathrm{x}$ & $\mathrm{x}$ & $\mathrm{x}$ & \\
\hline Asterales? & $\mathrm{x}$ & & & & \\
\hline Betulaceae & & & $\mathrm{x}$ & & \\
\hline Bignoniaceae & & $\mathrm{x}$ & & & \\
\hline Bursuraceae & & $\mathrm{x}$ & $\mathrm{x}$ & $\mathrm{x}$ & \\
\hline Caprifoliaceae & $\mathrm{X}$ & & & & \\
\hline Cannabaceae & & $\mathrm{x}$ & & & \\
\hline Cornaceae & $\mathrm{x}$ & & $\mathrm{x}$ & $\mathrm{x}$ & \\
\hline Cyclanthaceae & & $\mathrm{X}$ & & & \\
\hline Cyperaceae* & $\mathrm{x} ?$ & $\bar{x}$ & & & \\
\hline Elaeocarpaceae & & $\mathrm{x}$ & & & \\
\hline Euphorbiaceae & & $\mathrm{x}$ & & & \\
\hline Fagaceae & & & $\mathrm{x}$ & & $\mathrm{x}$ \\
\hline Grossulariaceae? & $\mathrm{x}$ & & & & \\
\hline Hamamelidaceae & & $\mathrm{x}$ & $\mathrm{x}$ & & \\
\hline Taxon/Family & Princeton & Messel & Clarno & London & Appian \\
\hline
\end{tabular}




\begin{tabular}{|c|c|c|c|c|c|}
\hline & chert & & Nutbeds & Clay & Way \\
\hline Hydrangaceae & & & $\mathrm{x}$ & & \\
\hline Icacinaceae & & $\mathrm{x}$ & $\mathrm{x}$ & $\mathrm{x}$ & $\mathrm{x}$ \\
\hline Juncaceae* & $\mathrm{x}$ & & & & \\
\hline Juglandaceae & & $\mathrm{x}$ & $\mathrm{x}$ & $\mathrm{x}$ & $\mathrm{x}$ \\
\hline Lauraceae & $\mathrm{x}$ & $\mathrm{x}$ & $\mathrm{x}$ & $\mathrm{x}$ & $\mathrm{x}$ \\
\hline Leguminosae & & $\mathrm{x}$ & $\mathrm{x}$ & & \\
\hline Liliales & $\mathrm{X}$ & & & & \\
\hline Lythraceae & $\mathrm{x}$ & $\mathrm{x}$ & $\mathrm{x}$ & $\mathrm{x}$ & \\
\hline Magnoliaceae & $\mathrm{x}$ & $\mathrm{x}$ & $\mathrm{x}$ & & \\
\hline Mastixiaceae & & $\mathrm{x}$ & & & \\
\hline Menispermaceae & & $\mathrm{x}$ & $\mathrm{x}$ & $\mathrm{x}$ & \\
\hline Musaceae & & & $\mathrm{x}$ & & \\
\hline Myristicaceae & & $\mathrm{x}$ & & & \\
\hline Myrtaceae & $\mathrm{x}$ & & & $\bar{x}$ & \\
\hline Nymphaeaceae/ales?* & $\mathrm{x}$ & x?-ales & & $\mathrm{x}$ & \\
\hline Nyssaceae & & $\mathrm{x}$ & & & \\
\hline Oleaceae & $\mathrm{x}$ & & & & \\
\hline Pentapylaceae & & $\mathrm{x}$ & & & \\
\hline Platanaceae & & $\mathrm{x}$ & $\mathrm{x}$ & & $\mathrm{x}$ \\
\hline Rhamnaceae & & $\mathrm{x}$ & & & \\
\hline Rosaceae & $\mathrm{x}$ & & $\mathrm{x}$ & & \\
\hline Taxon/Family & Princeton & Messel & Clarno & London & Appian \\
\hline
\end{tabular}




\begin{tabular}{|c|c|c|c|c|c|}
\hline & chert & & Nutbeds & Clay & Way \\
\hline Rubiaceae & & & $\mathrm{x}$ & & \\
\hline Rutaceae & & $\mathrm{x}$ & & $\bar{x}$ & \\
\hline Sabiaceae & & $\mathrm{x}$ & $\mathrm{x}$ & & \\
\hline Sapindaceae & $\mathrm{x}$ & & $\mathrm{x}$ & $\mathrm{x}$ & \\
\hline Sapotaceae & & $\mathrm{x}$ & $\mathrm{x}$ & & \\
\hline Simaroubaceae & & $\mathrm{x}$ & & & \\
\hline Symplocaceae & & & $\mathrm{x}$ & & \\
\hline Tapsicaceae & & $\mathrm{x}$ & & & \\
\hline Theaceae & & $\mathrm{x}$ & $\bar{x}$ & & \\
\hline Toricelliaceae & & $\mathrm{x}$ & & & \\
\hline Ulmaceae & & $\mathrm{x}$ & $\bar{x}$ & & \\
\hline Vitaceae & $\mathrm{x}$ & $\mathrm{x}$ & $\mathrm{x}$ & $\mathrm{x}$ & \\
\hline
\end{tabular}




\section{Figures.}

Figure 1. A. Princeton chert outcrop showing interbedded layers of chert and coal.

B. Group of Dennseteadtiopsis fern rhizomes and stipes.

C. Pinus arnoldii seed cone, oblique longitudinal section. Scale in $\mathrm{mm}$.

D. Matrix showing two Eorhiza rhizomes with adventitious roots emerging (rhizome at left). Scale in $\mathrm{mm}$. 


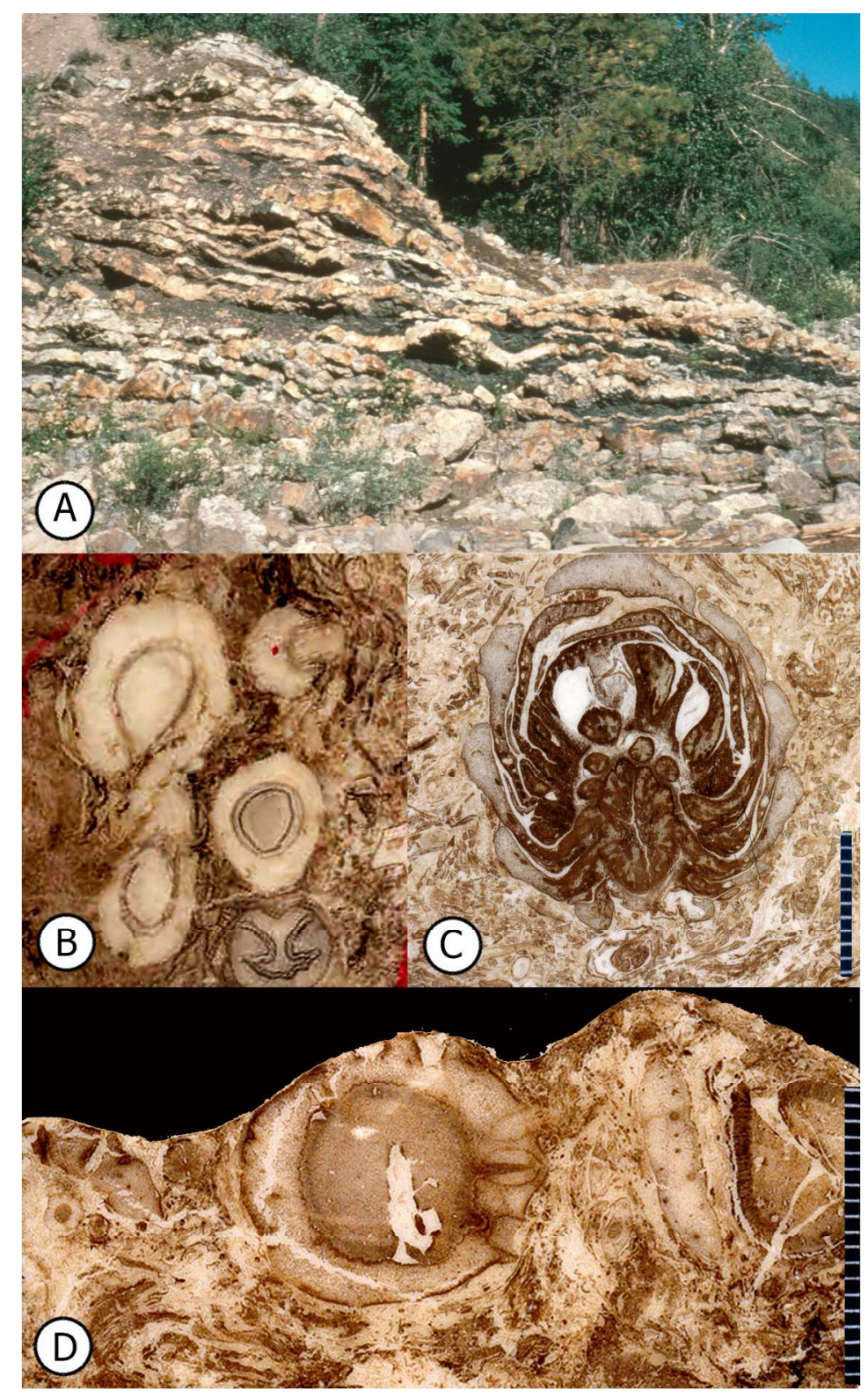

Plate 1

$139 \times 228 \mathrm{~mm}(300 \times 300 \mathrm{DPI})$ 


\section{Appendix A1. Plants of the Princeton chert.}

FERNS - Filicales - Osmundaceae Osmunda sp. (Collinson 2001)

- Dennstaedtiaceae Dennstaedtiopsis aerenchymata Arnold \& Daugherty (Arnold and Daugherty 1964; Cevallos-Ferriz et al. 1991)

- Blechnaceae Trawetsia princetonensis Smith, Stockey, Nishida \& Rothwell (Smith et al. 2006)

- Athyriaceae Makotopteris princetonensis Stockey, Nishida \& Rothwell (Stockey et al. 1999); Dickwhitea allenbyensis Karafit, Stockey, Rothwell \& Nishida (Karafit et al. 2006)

GYMNOSPERMS - Pinales - Pinaceae Pinus arnoldii Miller emend. Klymiuk, Stockey \& Rothwell (Miller 1973; Klymiuk et al. 2011; Stockey 1984; Phipps et al. 1995); Pinus similkameenensis Miller (Miller 1973); Pinus andersonii Stockey (Stockey 1984); Pinus princetonensis Stockey (Stockey 1984); Pinus allisonii Stockey (Stockey 1984)

- Cupressaceae Metasequoia milleri Basinger (Rothwell and Basinger 1979; Basinger 1981; Basinger 1984)

\section{ANGIOSPERMS}

ANITA Grade - Nymphaeales-Nymphaeaceae Allenbya collinsae Cevallos-Ferriz \& Stockey (Cevallos-Ferriz and Stockey 1989)

MAGNOLIIDS - Magnoliales - Magnoliaceae Liriodendroxylon princetonensis CevallosFerriz \& Stockey (Cevallos-Ferriz and Stockey 1990b)

Laurales - Lauraceae - Unnamed taxon (Little et al. 2009)

Piperales - Saururaceae Saururus tuckerae Smith \& Stockey (Smith and Stockey 
2007a, b); "Anemopsipolles" pollen (Ferguson et al. 2007)

\section{NON COMMELINID MONOCOTS}

Alismatales - Araceae, Subfamily Lasioideae Keratosperma allenbyense Cevallos-

Ferriz \& Stockey emend. SY Smith \& Stockey (Cevallos-Ferris and

Stockey 1988a; Smith and Stockey 2003)

- Alismataceae Heleophyton helobiacoides Erwin \& Stockey (Erwin and Stockey 1989)

- Apotogetonaceae Aponogeton longispinosum Grímsson, Zetter, \& Halbritter

(Grímsson et al. 2014)

Liliales - Family not designated Soleredera rhizomorpha Erwin \& Stockey (Erwin and Stockey 1991)

- cf. Iridaceae Pseudoararisteapolles stockeyi Zetter \& Hesse (Hesse and Zetter 2005)

COMMELINID MONOCOTS - Arecales - Arecaceae - Coryphoid palm Uhlia allenbyensis Erwin \& Stockey (Erwin and Stockey 1994)

Poales - Juncaceae/Cyperaceae Ethela sargentiana Erwin \& Stockey (Erwin and Stockey 1992)

\section{CORE EUDICOTS}

Saxifragales - Grossulariaceae Ribes sp. (?; Cevallos-Ferriz 1995)

Vitales - Vitaceae Ampelocissus similkameenensis Cevallos-Ferriz \& Stockey.

Seed type 1, Seed type 2 (Cevallos-Ferriz and Stockey 1990c)

ROSIDS - Rosids I - Fabidae - Rosales- Rosaceae Paleorosa similkameenensis Basinger

(Basinger 1976; Cevallos-Ferriz et al. 1993); Prunus allenbyensis 
Cevallos-Ferriz \& Stockey (Cevallos-Ferriz and Stockey 1990a); Prunus endocarps types 1, 2, 3 (Cevallos-Ferriz and Stockey 1991)

ROSID II - Malvidae - Myrtales - Lythraceae Decodon allenbyensis Cevallos-Ferriz \& Stockey (Cevallos-Ferriz and Stockey 1988b; Little and Stockey 2003;

Little et al. 2004; Grímsson et al. 2012)

- Myrtaceae Paleomyrtinaea princetonensis Pigg, Stockey \& Maxwell (Pigg et al. 1993)

Sapindales - Sapindaceae Wehrwolfea striata Erwin \& Stockey (Erwin and Stockey 1990)

ASTERIDS - Cornales - Cornaceae: Diplopanax eydei Stockey, LePage \& Pigg (Stockey et al. 1998)

Lamiales - Oleaceae (Manchester et al. 2015)

Asterales (?) - Asteraceae (?; Manchester et al. 2015)

Apiales - Araliaceae (Manchester et al. 2015)

Dipsicales - Caprifoliaceae (Manchester et al. 2015)

INCERTAE SEDIS - Eorhiza allenbyensis Robison \& Person (Robison and Person 1973;

Stockey and Pigg 1994)

Princetonia allenbyensis Stockey (Stockey 1987, Stockey and Pigg 1991) 


\section{References}

Arnold, C.A., and Daugherty, L.H. 1964. A fossil dennsteadtioid fern from the Eocene Clarno formation of Oregon. Contributions from the Museum of Paleontology, The University of Michigan, 19: 65-88.

Basinger, J.F. 1976. Paleorosa similkameenensis, gen. et. sp. nov., permineralized flowers (Rosaceae) from the Eocene of British Columbia. Canadian Journal of Botany, 54: 22932305.

Basinger, J.F. 1981. The vegetative body of Metasequoia milleri from the middle Eocene of southern British Columbia. Canadian Journal of Botany, 59: 2379-2410.

Basinger, J.F. 1984. Seed cones of Metasequoia milleri from the middle Eocene of southern British Columbia. Canadian Journal of Botany, 62: 281-289.

Cevallos-Ferriz, S.R.S. 1995. Fruits of Ribes from the Princeton chert, British Columbia, Canada. American Journal of Botany, 82 (supplement): 84.

Cevallos-Ferriz, S.R.S., and Stockey, R.A. 1988a. Permineralized fruits and seeds from the Princeton chert (middle Eocene) of British Columbia: Araceae. American Journal of Botany, 75: 1099-1113.

Cevallos-Ferriz, S.R.S., and Stockey, R.A. 1988b. Permineralized fruits and seeds from the Princeton chert (middle Eocene) of British Columbia: Lythraceae. Canadian Journal of Botany, 66: 303-312.

Cevallos-Ferriz, S.R.S., and Stockey, R.A. 1989. Permineralized fruits and seeds from the Princeton chert (middle Eocene) of British Columbia: Nymphaeaceae. Botanical Gazette 150: $207-217$. 
Cevallos-Ferriz, S.R.S., and Stockey, R.A. 1990a. Vegetative remains of the Rosaceae from the Princeton chert (middle Eocene) of British Columbia. IAWA (International Journal of Wood Anatomists) Bulletin n. s., 11: 261-280.

Cevallos-Ferriz, S.R.S., and Stockey, R.A. 1990b. Vegetative remains of the Magnoliaceae from the Princeton chert (middle Eocene) of British Columbia. Canadian Journal of Botany, 68: $1327-1339$.

Cevallos-Ferriz, S.R.S., and Stockey, R.A. 1990c. Permineralized fruits and seeds from the Princeton chert (middle Eocene) of British Columbia: Vitaceae. Canadian Journal of Botany, 68: 288-379.

Cevallos-Ferriz, S.R.S., and Stockey, R.A. 1991. Permineralized fruits and seeds from the Princeton chert (middle Eocene) of British Columbia: Rosaceae (Prunoideae). Botanical Gazette, 152: 369-379.

Cevallos-Ferriz, S.R.S., Stockey, R.A., and Pigg, K.B. 1991. The Princeton chert: evidence for in situ aquatic plants. Review of Palaeobotany and Palynology, 70: 173-185.

Cevallos-Ferriz, S.R.S., Erwin, D.M., and Stockey, R.A. 1993. Further observations on Paleorosa similkameenensis (Rosaceae) from the middle Eocene Princeton chert of British Columbia, Canada. Review of Palaeobotany and Palynology, 78: 277-291.

Collinson, M.E. 2001. Cainozoic ferns and their distribution. Brittonia, 53:173-235.

Erwin, D.M., and Stockey, R.A. 1989. Permineralized monocotyledons from the middle Eocene Princeton chert (Allenby Formation) of British Columbia: Alismataceae. Canadian Journal of Botany, 67: 2636-2645. 
Erwin, D.M., and Stockey, R.A. 1990. Sapindaceous flowers from the middle Eocene Princeton chert (Allenby Formation) of British Columbia, Canada. Canadian Journal of Botany, 68: $2025-2034$.

Erwin, D.M., and Stockey, R.A. 1991. Soleredera rhizomorpha gen. et sp. nov., a permineralized monocotyledon from the middle Eocene Princeton chert of British Columbia, Canada. Botanical Gazette, 152: 231-247.

Erwin, D.M., and Stockey, R.A. 1992. Vegetative body of a permineralized monocotyledon from the middle Eocene Princeton chert of British Columbia. Courier Forschungsinstitut Senckenberg, 147: 309-327.

Erwin, D.M., and Stockey, R.A. 1994. Permineralized monocotyledons from the middle Eocene Princeton chert (Allenby Formation) of British Columbia: Arecaceae. Palaeontographica Abteilung B, 234: 19-40.

Ferguson, D.K., Zetter, R., and Paudayal, K.N. 2007. The need for the SEM in palaeopalynology. Compte Rendus Paleo. 6: 423-430.

Grímsson, F., Ferguson, D.K., and Zetter, R. 2012. Morphological trends in the fossil pollen of Decodon and the paleobiogeographic history of the genus. International Journal of Plant Sciences, 173: 297-317.

Grímsson, F., Zetter, R., Halbritter, H. Grimm, G.W. 2014. Aponogeton pollen from the Cretaceous and Paleogene of North America and West Greenland: Implications for the origin and palaeobiogeography of the genus. Review of Palaeobotany and Palynology, 200: $161-187$.

Hesse, M., and Zetter, R. 2005. Ultrastructure and diversity of recent and fossil zona-aperturate pollen grains. Plant Systematics \& Evolution, 255: 145-176. 
Karafit, S.J., Rothwell, G.W., Stockey, R.A., and Nishida, H. 2006. Evidence for sympodial vascular architecture in a filicalean fern rhizome: Dickwhitea allenbyensis gen. et sp. nov. (Athyriaceae). International Journal of Plant Sciences, 167: 721-727.

Klymiuk, A.A., Stockey, R.A., and Rothwell, G.W. 2011. The first organismal concept for an extinct species of Pinaceae: Pinus arnoldii Miller. International Journal of Plant Sciences, 172: 294-313.

Little, S.A., and Stockey, R.A. 2003. Vegetative growth of Decodon allenbyensis (Lythraceae) from the middle Eocene Princeton chert with anatomical comparisons to Decodon verticillatus. International Journal of Plant Sciences, 164: 454-469.

Little, S.A., and Stockey, R.A. 2005. Morphogenesis of the specialized peridermal tissues in Decodon allenbyensis from the middle Eocene Princeton chert. IAWA (International Association of Wood Anatomists) Bulletin, 27: 73-87.

Little, S.A., Stockey, R.A., and Keating, R.C. 2004. Duabanga-like leaves from the middle Eocene Princton chert and comparative leaf histology of Lythraceae sensu lato. American Journal of Botany, 91: 1126-1139.

Little, S.A., Stockey, R.A., Penner, B. 2009. Anatomy and development of fruits of Lauraceae from the middle Eocene Princeton Chert. American Journal of Botany, 96: 637-651.

Manchester, S. R., Grímsson, F., and Zetter, R. 2015. Assessing the fossil record of asterids in the context of our current phylogenetic framework. Annals of the Missouri Botanical Garden, 100: 329-363.

Miller, C.N., Jr. 1973. Silicified cones and vegetative remains of Pinus from the Eocene of British Columbia. Contributions to the University of Michigan Museum of Paleontology, University of Michigan, 24: 101-118. 
Phipps, C.J., Osborn, J.M., and Stockey, R.A. 1995. Pinus pollen cones from the middle Eocene Princeton chert (Allenby Formation) of British Columbia, Canada. International Journal of Plant Sciences, 156: 117-124.

Pigg, K.B., Stockey, R.A., and Maxwell, S.L. 1993. Paleomyrtinaea princetonensis gen. et sp. nov., permineralized myrtaceous fruits and seeds from the Princeton chert and related Myrtaceae from Almont, North Dakota. Canadian Journal of Botany, 71: 1-9.

Robison, C.R., and Person, C.P. 1973. A silicified semiaquatic dicotyledon from the Eocene Allenby Formation of British Columbia. Canadian Journal of Botany, 51: 1373-1377.

Rothwell, G.W., and Basinger, J.F. 1979. Metasequoia milleri n. sp., anatomically preserved pollen cones from the middle Eocene (Allenby Formation) of British Columbia. anadian Journal of Botany, 57: 958-970.

Smith, S.Y., and Stockey, R.A. 2003. Aroid seeds from the middle Eocene Princeton chert (Keratosperma allenbyense, Araceae): comparisons with extant Lasioideae. International Journal of Plant Sciences, 164: 239-250.

Smith, S.Y., and Stockey, R.A. 2007a. Establishing a fossil record for the perianthless Piperales: Saururus tuckerae sp. nov. (Saururaceae) from the middle Eocene Princeton chert. American Journal of Botany, 94: 1642-1657.

Smith, S.Y., and Stockey, R.A. 2007b. Pollen morphology and ultrastructure of Saururaceae. Grana, 46: 250-267.

Smith, S.Y., Stockey, R.A., Nishida, H. and Rothwell, G.W. 2006. Trawetsia princetonensis gen. et sp. nov. (Blechnaceae): a permineralized fern from the middle Eocene Princeton chert. International Journal of Plant Sciences, 167: 711-719. 
Stockey, R.A. 1984. Middle Eocene Pinus remains from British Columbia. Botanical Gazette, 145: 262-274.

Stockey, R.A. 1987. A permineralized flower from the middle Eocene of British Columbia. American Journal of Botany, 74: 1878-1887.

Stockey, R.A., and Pigg, K.B. 1991. Flowers and fruits of Princetonia allenbyensis (Magnoliopsida: family indet.) from the middle Eocene Princeton chert of British Columbia. Review of Palaeobotany and Palynology, 70: 163-172.

Stockey, R.A., and Pigg, K.B. 1994. Vegetative growth of Eorhiza arnoldii Robison and Person from the middle Eocene Princeton chert locality of British Columbia. International Journal of Plant Sciences, 155: 606-616.

Stockey, R.A., LePage, B.A., and Pigg, K.B. 1998. Permineralized fruits of Diplopanax (Cornaceae, Mastixioideae) from the middle Eocene Princeton chert of British Columbia. Review of Palaeobotany and Palynology, 103: 223-234.

Stockey, R.A., Nishida, H. and Rothwell, G.W. 1999. Permineralized ferns from the middle Eocene Princeton chert. I. Makotopteris princetonensis gen. et sp. nov. (Athyriaceae). International Journal of Plant Sciences, 160: 1047-1055. 